
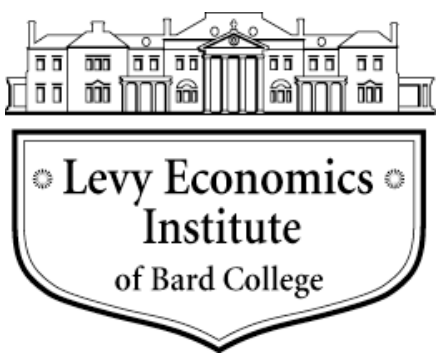

Working Paper No. 775

\title{
Wage and Profit-led Growth: \\ The Limits to Neo-Kaleckian Models and a Kaldorian Proposal
}

by

\author{
Esteban Pérez Caldentey \\ Economic Commission for Latin America and the Caribbean \\ Matías Vernengo* \\ Bucknell University
}

September 2013

* The opinions here expressed are the authors' own and may not coincide with those of the institutions with which they are affiliated. A preliminary version of this paper was presented at the Eastern Economic Association Meetings in New York, May 9, 2013. We thank the participants for their comments.

The Levy Economics Institute Working Paper Collection presents research in progress by Levy Institute scholars and conference participants. The purpose of the series is to disseminate ideas to and elicit comments from academics and professionals.

Levy Economics Institute of Bard College, founded in 1986, is a nonprofit, nonpartisan, independently funded research organization devoted to public service. Through scholarship and economic research it generates viable, effective public policy responses to important economic problems that profoundly affect the quality of life in the United States and abroad.

Levy Economics Institute

P.O. Box 5000

Annandale-on-Hudson, NY 12504-5000

http://www.levyinstitute.org

Copyright $(C$ Levy Economics Institute 2013 All rights reserved 


\begin{abstract}
We argue that a fundamental difference between Post-Keynesian approaches to economic growth lies in their treatment of investment. Kaleckian-Robinsonian models postulate an investment function dependent on the accelerator and profitability. Some of these models rely on the importance of profitability, captured by the profit share, to make the case for profit-led growth. For their part, Kaldorian models place the emphasis on the accelerator. More important, investment is a derived demand; that is, it is ruled by the adjustment of capacity to exogenous demand, which, in turn, determines the normal level of capacity utilization.

In our view, the Kaldorian approach is better equipped to deal with some of the issues relating income distribution to accumulation with effective demand in the long run. We develop a Kaldorian open-economy model to examine the conditions under which an increase in real wages can produce profit or wage-led growth, showing that the limit to a wage-led expansion is a binding external constraint. The role and limitations of wages as a determinant of growth are further examined through spectral techniques and cycle analysis for a subset of developed economies. The evidence indicates that real wages are positively related to growth, investment, and capacity utilization. It also highlights the role of finance in sustaining expansions, suggesting that debt-led growth should not be identified with profit-led growth.
\end{abstract}

Keywords: Kaldorian and Kaleckian Models; Profit-, Wage-, and Debt-Led Growth;

Investment; Derived Demand; External Constraint

\title{
JEL Classifications: B50, E32, 040
}




\section{INTRODUCTION}

Within the Post-Keynesian approach to economic growth, two distinct families of models have matured, drawing their basic inspiration from either Nicholas Kaldor or Michael Kalecki and Joan Robinson. A fundamental difference between these families of models lies in their treatment of investment.

Some of the modern Kaleckian-Robinsonian models, following Marglin and Bhaduri assume that, besides capacity utilization, investment is affected by the profit share, and on this basis make the case for a profit-led rather than a wage-led growth regime. Contrary to the views of Kalecki and earlier Kaleckian models (Rowthorn) they argue that a rise in the profit share serves as the stimulus to investment and growth, whereas a wage led growth regime may fail to generate the required growth in productive capacity. The arguments in favor of profit-led growth are further reinforced by open economy considerations where wage increases are seen as damaging to competitiveness.

We argue that Neo-Kaleckian models allow a limited role for demand and it is on this basis that the case for profit-led growth rests. In particular, the profit share component of investment represents supply side forces which tend to predominate over the accelerator which reflects demand side factors.

Kaldorian models place the emphasis on the accelerator rather than profitability. But more importantly, investment is considered a derived demand. The level of investment is ruled by the adjustment of capacity to exogenous demand which, in turn, determines the normal level of capacity utilization.

Using the notion of investment as a derived demand determined by the necessity of adjusting the actual capacity utilization to its normal long-term level we develop a Kaldorian open economy model that, from our point of view, is better equipped to deal with some of the issues relating income distribution to accumulation with effective demand in the long-run.

The model examines the conditions under which an increase in real wages can produce profit or wage-led growth. We argue that the limit to a wage led expansion is a binding external constraint. $^{1}$

\footnotetext{
${ }^{1}$ In this sense our model makes the connection between profit and wage led growth and the balance-of-payments constraint literature. See, McCombie \& Thirlwall (1994).
} 
The role of wages as a determinant of growth is analyzed empirically using spectral analysis and business cycle indicators for a subset of developed countries including the United States, France, United Kingdom, Canada, Germany, Italy, Australia and Japan. The results show for the most part that the rate of growth of real wages has kept pace with overall economic conditions. We also find a positive relation between real wages and growth and with investment and capacity utilization and high degree of cycle synchronicity between real wages, GDP, investment and exports.

The empirical analysis also notes the fact that real wages and consumption do not necessarily maintain a one-to-one relationship. It is important to note that while consumption is clearly dependent on income - with the old Keynesian tradition associated with Duesenberry suggesting that relative income was central ${ }^{2}$ - in economies with more developed financial systems, in which the bulk of consumption is done on credit, there is a relative autonomy of consumption, which may lead to debt-led growth processes. This has important implications for the understanding of the relation between income distribution and growth, and for economic policy, in particular after the 2008-9 Global Crisis.

The remainder of the paper is divided in four additional sections dealing with the limits of the Neo-Kaleckian models; the development of a Kaldorian model that shows, among others the importance of the external constraint, and how some results that seem compatible with profit-led results can be explained within a Kaldorian framework; an empirical analysis of the relation between income distribution, private debt and economic growth, and a brief conclusion.

\section{THE LIMITS TO 'KALECKIAN' (PROFIT-LED) MODELS}

The basis for the Kaleckian models of growth comes from Bob Rowthorn. For Rowthorn (1981), the basic premise of Kaleckian models is that growth is wage-led. In an economy operating below full-capacity it is the increase in the real wage rate participation in total income, achieved via nominal wage increases, that generates the demand necessary to call forth higher levels of output. This in turn raises the level of capacity utilization, and thus the rate of profit on the existing capital stock, inducing firms to invest. ${ }^{3}$

\footnotetext{
${ }^{2}$ For a recent exposition of Duesenberry's relative income hypothesis see Garegnani \& Trezzini (2005) and Palley (2010).

${ }^{3}$ In Rowthorn's model increased wages create extra profits that are then realized by the induced expenditure undertaken by capitalists on consumption and investment. Additionally it is important to note that the increase in
} 
The crucial point for our purposes is that the structure of Rowthorn's investment function is such that only a wage-led growth regime is possible. Rowthorn's investment function is a function of capacity utilization and profits, (1) $\frac{I}{K}=f(\pi, u)$

Where, $\pi$ and $u$ are profits and capacity utilization and $f_{\pi}^{\prime}>0 ; f_{u}^{\prime}>0$.

The introduction of capacity utilization as a determinant of investment in Eq. (1) is meant to capture the accelerator effect and is obviously absent at full capacity utilization (Ibid, p. 14). Note that the assumption underpinning the accelerator effect is that firms maintain a margin of unused capacity as a buffer stock to meet expected increases in future demand and to respond to unforeseen contingencies (p. 12). ${ }^{4}$

Yet, skepticism about the applicability of wage-led growth regimes to industrialized capitalist countries mounted. Blecker (1989) noted that in an open-economy framework, wageled growth would prove a successful strategy only if the economy was 'relatively closed' to foreign trade, in the sense of having low price elasticities of exports and imports, a low income elasticity of imports, and a small import to GDP ratio. ${ }^{5}$

capacity utilization results in economies of scale, which offset the effect of the rise in labour costs (higher real wages) on profits (Rowthorn, 1981, p. 2).

${ }^{4}$ Note that in the Post-Keynesian literature the investment function is generally expressed as a function of capacity utilization and profits. Thus by assumption the models assume the existence of spare capacity (e.g. Taylor, 1985; Dutt, 1990; Marglin and Bhaduri, 1990; Lavoie, 1992). According to Rowthorn this accelerator effect 'is absent at full capacity' and in this sense capacity utilization is not part of the neo-Keynesian authors specification of the investment function. Either these assume that the economy operates at full capacity (Kaldor) or that capacity utilization remains constant at its normal level (Robinson 1956, 1962 and Kahn, 1959). On this point see, Stockhammer (1999), Palumbo, (2003) and Lavoie (2006). Note however that Kaldor did use the accelerator (in the sense of investment being a function of output), even in spite of Keynes criticisms, in his 1940 trade cycle paper and in his growth. In his correspondence with Keynes in 1939 (see Kaldor 1939 in Marcuzzo \& Rosselli, 2005) Kaldor mentioned that in the literature at the time the accelerator denotes both $I=f(Y)$ and $I=f\left(\frac{d Y}{d t}\right)$ and that in his trade cycle paper he used the former formulation. Kaldor eventually rejected the use of the linear accelerator as part of trade cycle theory (Kaldor, 1951). However he kept the accelerator as a crucial piece of his growth models (see, Kaldor, 1957, p. 601 and 1960, p. 215) but with a role confined to the short-run. Only later did Kaldor become aware of the accelerator as a determinant of long-run growth (Kaldor, 1970).

${ }^{5}$ Blecker presents closed economy and open economy scenarios. In a closed economy the mark-up is assumed to be fixed so that an increase in labor costs are fully passed in the form of higher prices and the relative income shares do not change. Higher nominal wages only affects the price level and a higher wage share can only occur through a discretionary reduction in the mark-up (p. 399). The wage share as other components of aggregate demand (i.e., government expenditure) is then positively related to capacity utilization and the desired rate of capital accumulation. By contrast in an open economy the mark-up is variable (a function of the target mark-up and the real exchange rate) and as a result the wage share is dependent on labor costs (and thus on higher nominal wages) besides depending on the mark-up. Labor costs are also inversely related to the real exchange rate. As a result in an open economy an increase in nominal wages translates into a higher wage share and an appreciation of the real exchange rate. This is turn worsens the competitive position causing a deterioration of the balance of trade. The deteriorating relative price (cost) effect of higher wages on the balance of trade is reinforced by the import elasticity 
The Kaleckian models basically normalize the IS identity by the capital stock, assume (in the extreme case) that the propensity to save out of wages is zero, and a propensity to save out of profits (s) between zero and one, and in Keynesian fashion have investment determine savings. The difference with the short-run story is that now accumulation (investment-to-capital ratio) determines income distribution (the rate of profits), a result often referred to as the Cambridge equation.

Marglin \& Bhaduri (1990), Bhaduri \& Marglin (1990), and Bhaduri (2008) argue that investment and savings are functions of the profit share $(\mathrm{h})$ and capacity utilization $(\mathrm{z})$ which is a predictor for expected or future demand ${ }^{6}$. In other words:

(2) $\mathrm{I}(\mathrm{h}, \mathrm{z})=\operatorname{shz}$ where $I^{\prime}(h)$ and $I^{\prime}(z)>0$.

The savings function assumes that in the short run full capacity output $\left(Y^{F E}\right)$ is a constant. This follows from the fact that total savings (S) are obtained through profits (i.e., workers do not save) and that total profits (P) are equal by definition to the profits share (h) times capacity utilization (z) times full employment output $\left(Y^{F E}\right)$. Formally,

(3) $S=s P=s \frac{P}{Y} \frac{Y}{Y^{F E}} Y^{F E} 7$

Setting $Y^{F E}=1$ (Bhaduri and Marglin, 1990, p. 377) then total savings can be expressed as a function of the profits share $(\mathrm{h})$ and capacity utilization (z) (i.e., $\mathrm{S}=\mathrm{sP}=\mathrm{s} \frac{\mathrm{P}}{\mathrm{Y}} \frac{\mathrm{Y}}{\mathrm{Y}^{\mathrm{FE}}}=\mathrm{shz}$ ). Since these authors assume that labor productivity is constant (Schutz, 2011) then a rise (decline) in the real wage will necessarily translate into a decline (rise) of the profit share and hence by Eq. (3) a rise (decline) in the real wage decreases (increases) total savings. ${ }^{8}$ Investment

of income effect (demand effect). The negative effect of the balance of trade on the rate of accumulation outweighs the positive effect of greater demand due to higher wages. The analysis seems to imply that besides the case of an economy closed to foreign trade, in an economy starting in a situation of very high excess capacity a wage-led growth strategy leads to a higher rate of accumulation (p. 410).

${ }^{6}$ Marglin \& Bhaduri (1990) and also Bhaduri (2008) measure profitability by using the profit share (h) instead of the profit rate (r) as in Rowthorn (1981).

7 This can be derived from Bhaduri \& Marglin's (1990, p. 379) definition of the rate of profit, $r=\frac{P}{K}=\left(\frac{P}{Y}\right)\left(\frac{Y}{Y^{F E}}\right)\left(\frac{Y^{F E}}{K}\right) \Leftrightarrow K r=P=\left(\frac{P}{Y}\right)\left(\frac{Y}{Y^{F E}}\right) Y^{F E}$

${ }^{8}$ Blecker (1989) also assumes throughout most of his core analysis constant labor productivity. Note that in Rowthorn (1981) labor productivity is not assumed constant. Below full capacity, a rise in demand leads to greater output and average productivity increases. Higher profits result from a more efficient use of labor (pp.9-10). In this sense if there is a rise in costs provoked by wages is more than offset by productivity gains. 
is a positive function of both the profit share (h) and capacity utilization ( $\mathrm{z})$ and is specified as a proportion of full capacity utilization output $\left(Y^{F E}\right.$ with $\left.Y^{F E}=1\right)$.

Bhaduri \& Marglin (1990, pp. 379-380) justify the specification of investment as a function of the profit share rather than the profit rate on two grounds. First, it avoids double counting. Second, and more importantly, the specification of investment as a function of capacity utilization and the profit rate (u,r) (as in Rowthorn, 1981) rules out 'the very possibility of profit led growth' so that only wage led growth is possible. ${ }^{9}$ According to both replacing the profit rate by the profit share corrects both flaws in the specification of the investment function.

Equating savings (Eq. 3) and investment (Eq. 2) and taking the total differential yields, $(4) d I(h, z)=d \operatorname{sh} z$

Solving for $\mathrm{z}$ and deriving with respect to $\mathrm{h}$ we have:

(5) $\frac{d z}{d h}=\frac{I_{h}^{\prime}-s z}{s h-I_{z}^{\prime}}$

Where $\mathrm{I}_{\mathrm{h}}$ is the response of investment to profitability and $\mathrm{I}_{\mathrm{Z}}$ to capacity utilization. The model assumes that the Keynesian stability condition that savings is more responsive to changes in income (output) or capacity utilization; thus $s h>I^{\prime}{ }_{z}$. Assuming Keynesian stability, the sign of the equation depends on the numerator.

If investment is strongly responsive to profitability $\left(\mathrm{I}_{\mathrm{h}}>\mathrm{sz}\right)$, then the system is profitled (exhilarationist) and a higher profit share translates into higher capacity utilization. Contrarily $\left(\mathrm{I}_{\mathrm{h}}<\mathrm{sz}\right)$, the wage-led (stagnationist) regime prevails and a higher profit share leads to lower capacity utilization.

Bhaduri \& Marglin (1990) argue furthermore that a stagnationist regime not only implies that an increase in the profit share due to lower real wages leads to lower capacity utilization

\footnotetext{
${ }^{9}$ The double counting argument can be seen by expressing the rate of profit $(r)$ as a function of the profit share in output $\left(\frac{P}{Y}\right)$, the rate of capacity utilization $\left(\frac{Y}{Y^{F E}}\right)$ and the full capacity output-capital ratio $\left(\frac{Y^{F E}}{K}\right)$. i.e., $r=\frac{P}{K}=$ $\left(\frac{P}{Y}\right)\left(\frac{Y}{Y^{F E}}\right)\left(\frac{Y^{F E}}{K}\right)$. From this formulation, if follows that both capacity utilization $\left(\frac{Y}{Y^{F E}}\right)$ and the profit share $\left(\frac{P}{Y}\right)$ affect investment through their influence on the rate of profit. Hence there is no need to include a separate term for capacity utilization once the rate of profit is included as the independent variable. However, if the rate of profit appears as the sole explanatory variable the effect of capacity on investment is not captured adequately (Bhaduri \& Marglin, p. 380).
} 
$\left(\frac{d z}{d h}<0\right)$ but that it can also lead to lower total profits $\left(\frac{d(h z)}{d h}<0\right)$ and that this is the only possible result if investment is specified as a function of the rate of profit $(r)$ and capacity utilization $(z)$. In other words an investment function of the type $I(r, z)$ rules out the very possibility and existence of profit-led growth. ${ }^{10}$ Hence the need to specify investment as a function of capacity utilization (z) and the profit share (h) as these authors propose.

According to these authors the justification for a profit-led regime relies on the fact that wage led growth may fail to generate the required growth in productive capacity and end up in a crisis of under accumulation. The argument for a profit-led regime is reinforced by their analysis of an open economy centered on the effects of a change in the nominal exchange rate.

The neo-Kaleckian growth models allow a very limited role for demand and it is on this basis that the case for profit-led growth rests. Full capacity (i.e., full employment) utilization (output) is defined independently of demand. It is in fact the equivalent of the Harrodian natural rate of growth in that it sets a physical limit to the expansion of output. Demand (and capacity utilization) adjusts to the independently given full capacity utilization. In other words, the actual rate of growth of output tends to converge to its 'natural rate' or, to put it more bluntly, demand adjusts to supply.

Within this framework the accelerator can only be operational in the short-run conceived either as a determinant of cycles and fluctuations or of a short-run growth path. At full capacity utilization the accelerator effect ceases to operate since by definition output cannot increase.

Moreover, even within the short-run, the role of demand is further constrained by the fact that the effect of the accelerator on investment is mediated by that of the profit share. A higher profit share captures expectations of higher expected profits and firms invest in

\footnotetext{
${ }^{10}$ Their reasoning is as follows (pp. 391-392). Let the investment function be defined as, $(\ldots) I=f\left(z, \frac{r}{z a}\right)$, where $\frac{r}{z a}=\frac{h z a}{z a}=h$
}

At a constant rate of profit the total differential of investment is equal to,

(...) $\frac{d I}{d z}=I_{z}-\left(\frac{h}{z}\right) I_{h}$

This implies that if investment is a function of capacity utilization $(\mathrm{z})$ and the profit rate (r) (i.e., $(I(z, r))$, and $I^{\prime}{ }_{z}>0$, then $\frac{d I}{d z}=I_{z}-\left(\frac{h}{z}\right) I_{h}>0$ and $z I^{\prime}{ }_{z}>h I^{\prime}{ }_{h}$. Investment is more responsive (i.e. elastic) to capacity utilization than to the profit share, which is in line with the stagnationist view. As Bhaduri \& Marglin (1990) put it, an investment function dependent of capacity utilization $(z)$ and the profit rate $(r)$ is 'tantamount to assuming a cooperative stagnationist regime.' 
additional capital because their expected returns are high. These return expectations are static and are not necessarily related to demand. As put by Bhaduri \& Marglin (1990, p. 380):

"The investment behavior... may be imagined to be based on static expectations... current average profitability... and average degree of capacity utilization... are used by investors as predictors of marginal profitability on new investment and the future state of demand respectively... The investment function... has the analytical advantage of clearly separating the 'demand side' impact on investment operating through the acceleration effect of higher capacity utilization from the 'supply side' impact operating through the cots-reducing effect of a lower real wage and higher profit margin/share."

Hence ultimately the predominance of supply over demand side factors provides the rationale for profit-led growth. Such a view is reinforced by the fact that a key tenant of the analysis is the supply side effect of wages. The effect of wages is on the profit share and both have an inverse relationship because productivity is assumed constant. ${ }^{11}$

\section{A GENERALIZED KALDORIAN APPROACH}

The independent investment function suggests that not only capacity utilization affects capital formation, but also the share of profits. The accelerator says that if capacity is low there is more investment, and vice versa when $\mathrm{z}$ is high. In other words, firms would try to adjust capacity to demand. If that were the case one would expect that a normal relation between capacity and demand would be established in the long run (in the neoclassical view demand adjusts to capacity; that's Say's Law). Investment is determined by the adjustment of capacity to exogenous demand in order to reach the normal capacity utilization, and it is essentially derived demand (the accelerator principle). ${ }^{12}$ It is not instrumental in determining the normal level of capacity utilization, which must be determined by the exogenous components of demand. This is the basis of the supermultiplier models (Serrano, 1995; Bortis, 1996). ${ }^{13}$

That is the essential difference between the Kaleckian and Kaldorian models, whether investment is partially autonomous and determined by profitability or it is derived demand. Of

\footnotetext{
${ }^{11}$ See for example Robinson (1956) and Dutt (2012) and Ros \& Dutt (2012) for the argument that tight labor conditions and thus pressure to increase wages leads to productivity improvements.

${ }^{12}$ We may want to think that the adjustment of capacity to autonomous demand can be considered a norm (in the sense of Godley \& Cripps, 1983) underlining sustainable dynamics for growth playing a similar role to that of the norm between money flows and assets (Ibid). Obviously in a monetary production economy both are intrinsically related.

${ }^{13}$ Note that what we refer to as Kaldorian models are sometimes denominated Sraffian in the literature. See Cesaratto (2013) for a Sraffian perspective of the debate between Neo-Kaleckians and Kaldorians.
} 
course income distribution in Kaldorian models might have ambiguous effects on growth, but firms would not invest more if profits went up, if there is no increase in demand. In this sense, worsening income distribution might lead to higher growth if demand keeps going up for some reason (say more private debt stimulates consumption; or stimulates the consumption of a higher income group). ${ }^{14}$

Further, since growth was in his view wage-led, these countries could not develop domestic markets and promote growth. Kaldorian models might be better prepared to deal with some of the issues relating income distribution to accumulation with effective demand in the long run. ${ }^{15}$ The Kaldorian models do not depend on the Cambridge equation equilibrium, which by equating savings to the exogenous investment function, are forced to treat capital accumulation as autonomous demand, and forgo the possibility of dealing with the capacity effect of investment. As noted by Bortis (1997), the Kaleckian-Robinsonian model can only deal with changes in the proportions of output in the investment and consumption goods sectors, but not with the determination of the potential output level. For that one must assume that investment is derived demand, and introduce in the model the full effects of capacity adjustments to changes in autonomous demand.

The model describes the dynamics of effective demand and income distribution in an open economy. Income determination follows traditional Keynesian lines, and can be written as:

$$
\frac{\dot{y}}{y}=\delta(\kappa-y)+\phi \hat{a}(\mu \omega+\varphi d)+\psi \varepsilon(z-m)
$$

Where $\mathrm{k}$ is capital and $\mathrm{y}$ is output and $\delta$ is the 'acceleration coefficient', $\phi$ is the multiplier coefficient, a-hat is the rate of growth of the autonomous component of domestic demand, $\omega$ is the real wage, and $\mu$ is the share of wages in total income, so that $\mu \omega$ is the share of wages in total income, $\mathrm{d}$ is the debt-to-income ratio of private agents, $\psi$ is the elasticity of

\footnotetext{
${ }^{14}$ Interestingly enough, Prebisch (1949) who was dealing with the problems of economic expansion in the periphery was, from a normative point of view, concerned with wage-led growth. Note that his explanation for the tendency of terms of trade of commodities to fall over time (the so-called Prebisch-Singer hypothesis) was based on the fact that in the boom wages went up in the center, but not so much in the periphery, since industrial workers in the center were organized and could demand higher salaries, while that was not possible for the agricultural and mining workers in the periphery. So in the recession, while prices of commodities and wages fell in the periphery, they did not collapse in the center. Bargaining power and not just technological change, was at the heart of the asymmetries between the center and the periphery.

${ }^{15}$ Kaldor and Prebisch were in contact during the 1950s, when Kaldor taught courses at ECLAC in Mexico. Not surprisingly there is an affinity between Kaldorian models, as formalized by McCombie \& Thirlwall (1994), and structuralist models in the vein of Prebisch.
} 
output with respect to net export growth for a given exchange rate, $\mathrm{z}$ is foreign demand, $\mathrm{m}$ is the import coefficient and is between zero and one, the coefficients $\delta, \varphi, \mu$, and $\phi$ are all positive, and $\psi$ has an ambiguous sign. ${ }^{16}$ In other words, output growth is the result of exogenous or autonomous demand components, which include next exports, but also of the share of wages in total income, on the level of private indebtedness. ${ }^{17}$

Note that this can be compared to a fairly conventional Kaleckian derivation of the multiplier, with the propensity to consume out of wages equal to one, and the propensity to consume out of profits equal to zero, which implies that a higher participation of wages in income would lead to an increase in output. Note that the model is strictly wage-led, as was the original Kaleckian model, as well as latter formalization by Rowthorn (1981), Dutt (1984) and Taylor (1985), but does not depend on the Cambridge Equation like those models.

There is an important assumption implicit in equation (1). It is presumed that if output, $\mathrm{y}$, is above the capital stock of equilibrium, $\mathrm{k}$, then there is less investment and the rate of output growth slowdown accordingly, and vice-versa when output is below the optimal capital level.

The idea is that there is a normal capital to output ratio that firms try to maintain, and that would be equivalent to a normal level of capacity utilization. In this sense, the first part of equation (1) corresponds to the accelerator principle, and by putting the accelerator and the multiplier model together we obtain a dynamic version of the so-called supermultiplier. In other words, the level of output determined above is the fully adjusted long-term level of output, once the capacity effect of investment is taken into account. In this sense, and contrary to Cambridge Equation models ${ }^{18}$ in which investment is autonomous, it deals with the determination of long-term output adjusted to capacity, and not just with the sectoral composition of the level of output (Bortis, 1997, p. 136).

Total supply is given by profits, wages and imports. Normalizing and dividing everything by the output level we have the following equation:

\footnotetext{
${ }^{16}$ Equation (1.) is essentially a multiplier that includes an accelerator term that in this model suggests that accumulation would be associated to a certain normal capital-output ratio. The multiplier cum accelerator was termed a supermultiplier by John Hicks, and is typical of Kaldorian models of growth. For discussions of Kaldorian models see McCombie \& Thirlwall (1994) and Bortis (1997). On the supermultiplier see Serrano (1995).

${ }^{17}$ For other models that include the role of debt in growth dynamics see Palley (1994), Dutt (2005) and Lima \& Meirelles (2007).

${ }^{18}$ Note that the Cambridge Equation will hold at different levels of output, and cannot be a theory of the determination of the fully adjusted level of output, since investment is taken to be autonomous, and its capacity effect on output is not taken into consideration, just its income effect (Bortis, 1997, pp. 164-5).
} 


$$
\pi+\omega b+\varepsilon m=1
$$

Where, $\pi$ is the share of profits in total income $\omega$ is the real wage, $b$ is the inverse of labor productivity, e is the real exchange rate, and $\mathrm{m}$ is the import coefficient. Further, the rate of change of the real exchange rate behaves according to the following rule:

$$
\frac{\dot{\varepsilon}}{\varepsilon}=(\alpha-1) \frac{\dot{p}}{p}-\frac{\dot{f}}{f}
$$

Where $\varepsilon$ stands for real exchange rate, $\mathrm{p}$ for domestic price level and $\mathrm{f}$ are financial inflows, $0<\alpha<1$. For this and the other equations of the model dots refer to changes in levels of the variables and asterisks for foreign variables. Thus equation (3.) states that the real exchange rate is an inverse function of the rate of inflation, and is negatively related to financial inflows, that is, inflows lead to a fall in the domestic price of foreign exchange, which stands for an appreciation of the domestic currency.

In turn, financial inflows are postulated as a function of the difference between nominal foreign and domestic interest rates ( $\mathrm{i}$ and $\mathrm{i}^{*}$ ), reflecting arbitrage opportunities, and respond positively to an increase output above the level that corresponds to normal capacity, in other words, real variables, and not just financial might also affect the flows of capital. That is:

$$
\frac{\dot{f}}{f}=\gamma\left(i-i^{*}\right)-\beta(\kappa-y)
$$

Where $\beta>0$ and $\gamma>0$. The next step is the description of the distributive conflict dynamics. Conflict over income distribution is represented by the behavior of firms, which increase prices whenever the share of profits falls below the normal level. ${ }^{19}$ This is represented as follows:

$$
\frac{\dot{p}}{p}=\bar{\pi}-\pi
$$

\footnotetext{
${ }^{19}$ There would be no significant change if we had conflict determined by a situation in which real wages respond to a situation in which they are below the level desired by workers.
} 
Where $\pi$-bar is the target or normal profit share desired by capitalists. ${ }^{20}$ From (2.) (4.) and (5.), we can rewrite (3.) as follows:

$$
\frac{\dot{\varepsilon}}{\varepsilon}=(\alpha-1)(\bar{\pi}-1+\omega b+\varepsilon m)+\beta(\kappa-y)-\gamma\left(i-i^{*}\right)
$$

Equations (1.) and (3'.) form a dynamic system that determines the real exchange rate, compatible with a stable income distribution setting, and the level of long-term equilibrium output of the economy, represented in Figure 1.

Figure 1

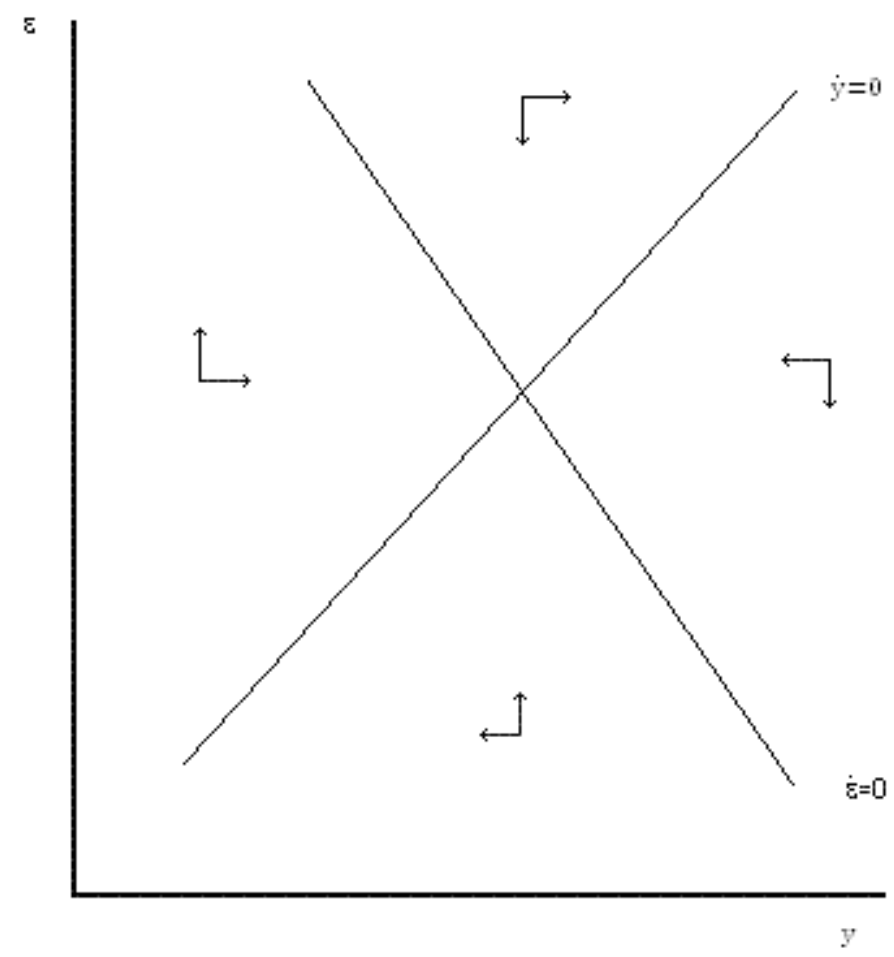

Equation (3'.) suggests that an increase in capacity utilization tends to attract capital flows and leads to a real appreciation, which is represented by the negatively sloped $\varepsilon$-dot

\footnotetext{
${ }^{20}$ The presumption is that capitalists always manage to get on the target profit share, and hence, an increase in the real wage must necessarily lead to a real appreciation through higher inflation. We do not model the nominal exchange rate dynamics, but what is needed for a real appreciation is that the rate of inflation is higher than the nominal depreciation, if there is one. Alternative one might think, for simplicity, that the nominal exchange rate is fixed.
} 
schedule. Equation (1.) just suggests that net exports respond to real exchange depreciations positively, and lead to output increase, displayed in the positively sloped y-dot schedule. The solution of the dynamic system, under certain circumstances, provides a stable node, and allows for simple comparative static analysis. ${ }^{21}$ The outcome reflects the long-term effective demand forces, and the distributive conflict, and allows the understanding of the effects of income distribution on the potential or normal level of output, in an open economy.

Let's assume that the real wage expands, this would reduce the actual profit share, lead to higher prices and a more appreciated real exchange rate. This would be represented by an inward shift of the $\varepsilon$-dot schedule, and would reduce the level of output, since it would have a negative impact on net exports, and through the multiplier would lead to a reduction in income, moving along the y-dot curve. On the other hand, the increase in wages would have a direct positive impact on the share of wages in total income and would increase the effects of autonomous spending on normal output. Consequently, spending would stimulate output growth moving the y-dot curve outwardly.

The final effect of the combination of higher real wages would depend on the relative negative impact of wages on net exports, through its impact on the real exchange rate, and the positive effect on spending. Figure 2 shows a situation in which appreciation of the real exchange rate goes hand in hand with the contraction of output, moving from E0 to E1. ${ }^{22}$ This represents the conventional Kaleckian argument that an economy that is essentially wage-led could have a profit-led result, once the open economy complications are brought to the forefront of the analysis. Note that the system is not per se profit-led, in the sense that investment is still

\footnotetext{
${ }^{21}$ The Jacobian matrix that determines the local stability properties of the system is: $\left[\begin{array}{ll}-\delta & \psi(z-m) \\ -\beta & (\alpha-1) m\end{array}\right]$

Stability requires that $|J|>0$ and that the $\operatorname{tr}(\mathrm{J})<0 \Leftrightarrow-\delta(\alpha-1) m+\beta \psi(z-m)>0$ and $-\delta+(\alpha-1) m<0$. Under plausible conditions the system might be stable. In fact since $\alpha-1<0$ and $m>0$, the trace $(\operatorname{tr}(\mathrm{J}))$ is negative. Since in addition $\beta>0$ and $(z-m)>0$, the determinant of the Jacobian $(|J|)$ will be positive, and the system will be stable if $\psi \geq 0$, that is if the elasticity of output with respect to net export growth for a given exchange rate is greater or equal to 0 . If $\psi<0$, stability requires that $\frac{z}{m}<1 t \frac{\delta(\alpha-1)}{\psi \beta}$ which is unlikely. Finally, the system admits the possibility that $|J|=0$ and thus display a continuum of equilibria, however this requires an unrealistically large value of the accelerator coefficient $\delta$, i.e., $\delta=\frac{\frac{z}{m}-1}{\alpha-1}$.

In Figure 1 we are assuming that $\psi(\mathrm{z}-\mathrm{m})$ is positive, and that a real depreciation is expansionary. If $\psi(\mathrm{z}-\mathrm{m})$ is negative, but the y-dot curve cuts the $\varepsilon$-dot curve from above the system would also be stable, if not it would be a saddle-path.

${ }^{22}$ The requirement for a 'profit-led' type of outcome is given by: $\phi \hat{a} \mu m<b \psi(z-m)$.
} 
pretty much determined by the accelerator, and is derived demand. It is the open economy effect of a change in income distribution that trumps the positive effects of higher real wage on spending and output.

Figure 2

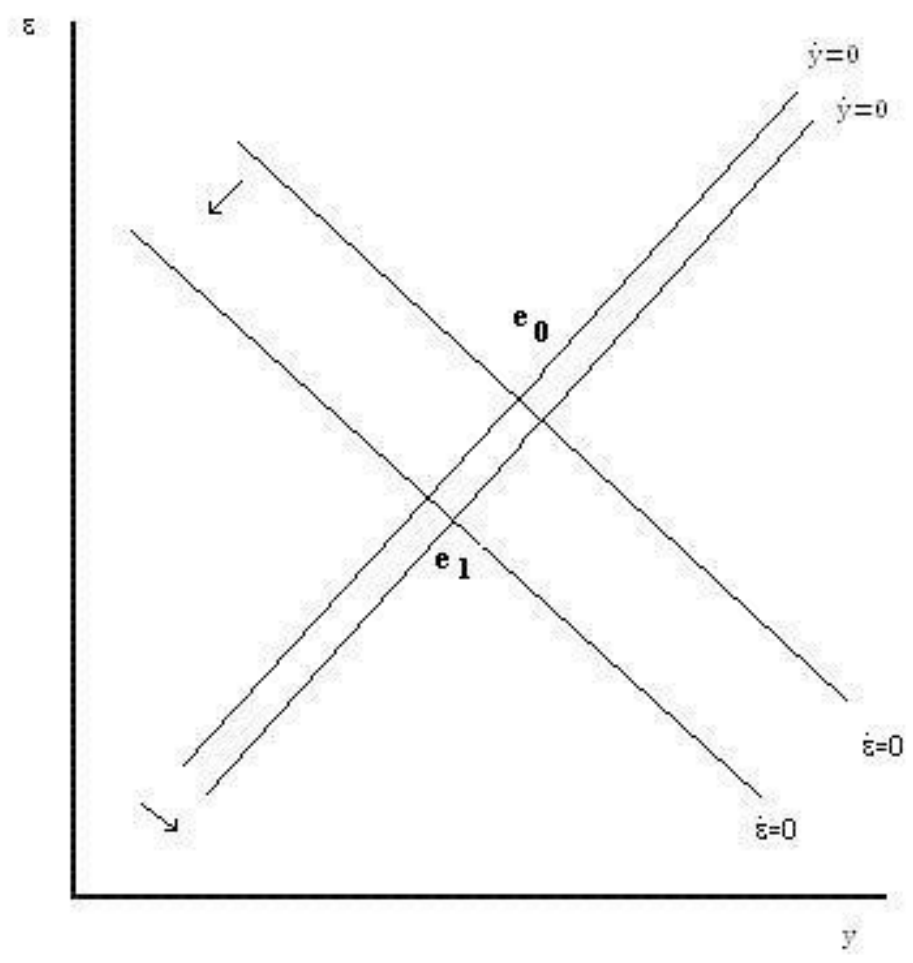

One possible way of looking at the problem is that exports do not respond significantly to the appreciation, another would be to assume that the import coefficient is relatively high, or a combination of both, so that an appreciation has a significant negative impact on net exports. Further, if one had the same parameters as above an export-led strategy based on lower wages to expand exports would be more than sufficient to promote higher levels of activity, which could be simply thought of as the reverse move from E1 to E0. This is the well-known effect of what has been termed in the literature 'a race to the bottom.'

Note, however, that if the conditions are different, and the effects of higher wages on domestic demand are larger than their negative impact on competitiveness, then one might actually encounter a wage-led regime in an open economy. Further, for developed countries that do not face a sharp external constraint like the US, growth can be stimulated by the effect of 
higher indebtedness on spending without a concern for the real exchange rate. The likelihood of a debt-led, rather than a profit-led regime tout court, which is barred in this formalization, increases.

Figure 3

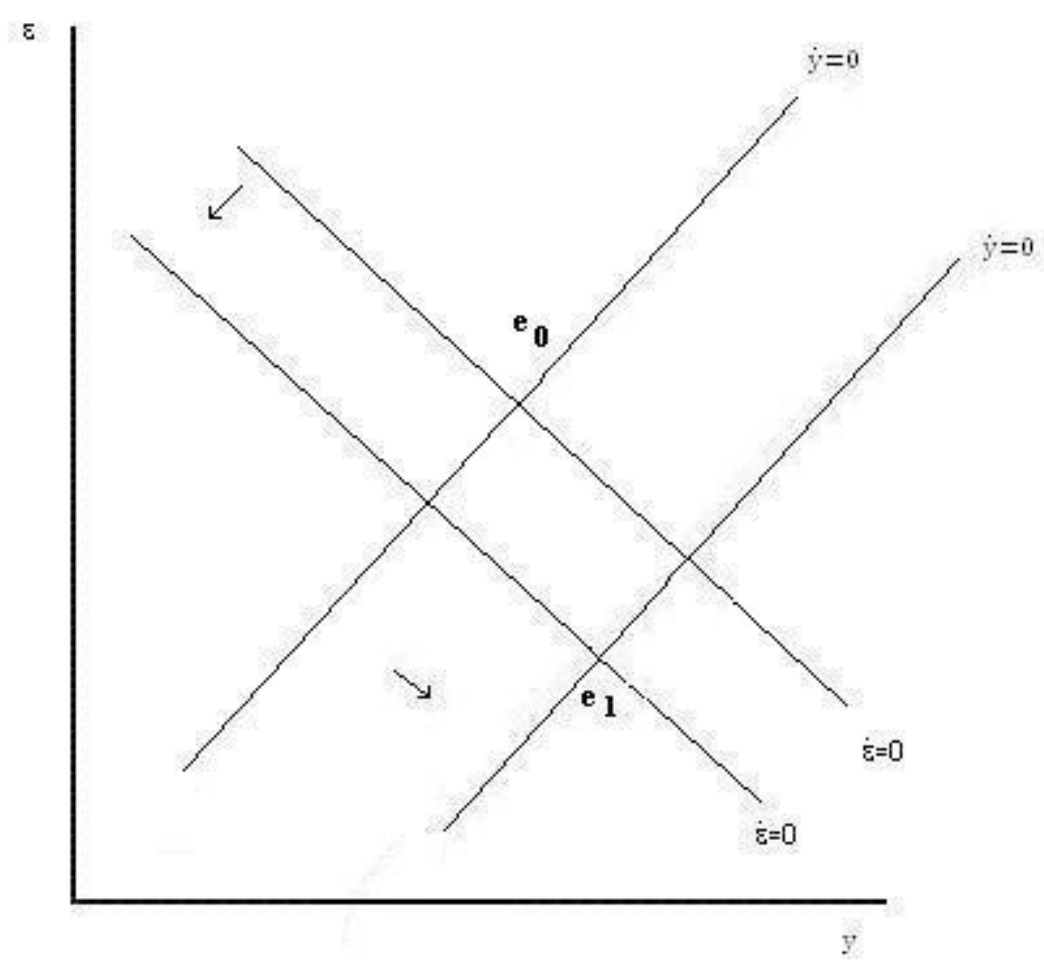

This situation is represented in Figure 3, in which the increase in wages still moves the $\varepsilon$-dot curve downwards, but that is more than compensated by the expansion of demand on potential output. Note that in this case a higher potential output would go hand in hand with a more appreciated currency, and vice versa, if we think of a reduction in real wages or the participation of wages in total income. In other words, this would be the long term equivalent of the Krugman \& Taylor (1978) argument for contractionary depreciation. In this case, potential output would be reduced by the real depreciation of the domestic currency.

The result would be significantly different if an appreciation does not have a negative effect on net exports. In this case, $\psi$ would be negative, implying that higher wages that lead to a real appreciation of the currency would not decrease exports, which would be affected proportionally more by foreign demand $\mathrm{z}$ than the real exchange rate, and imports would not 
significantly increase. In that case, with the addition of the expansionary effect of a higher wage share on spending the new equilibrium will be represented by Figure 4 .

Figure 4

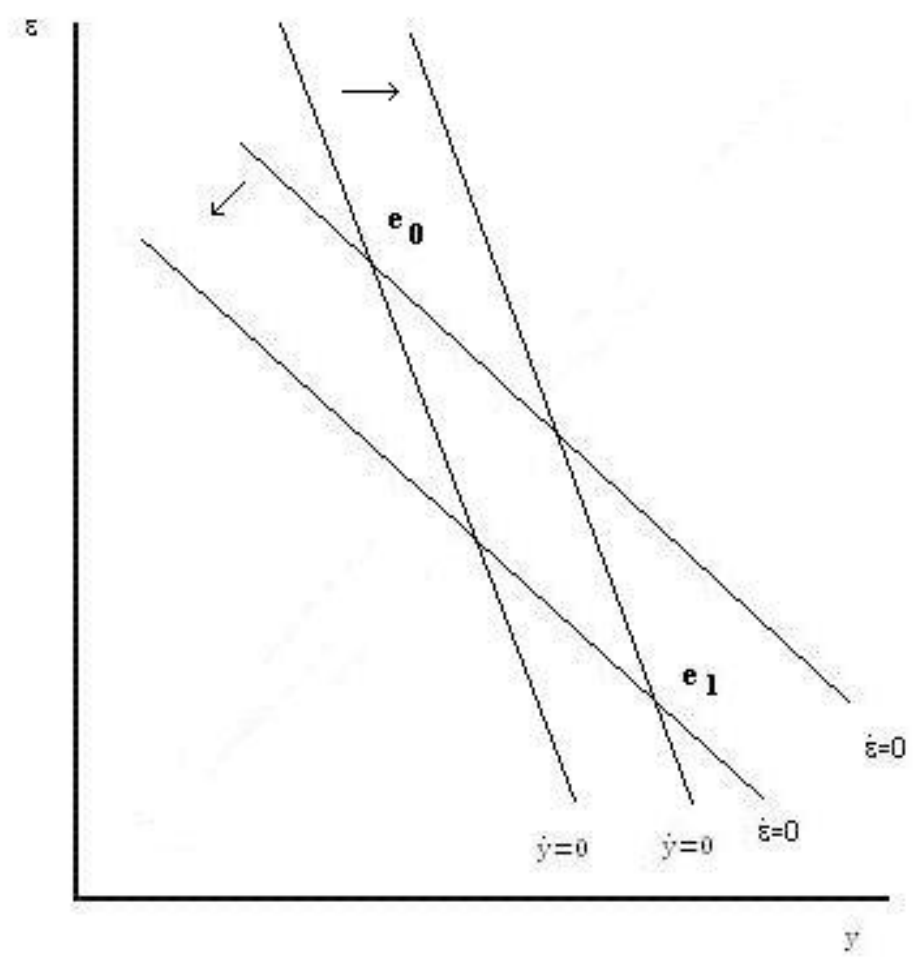

In this case the increase in real wages and the real exchange rate appreciation would be unequivocally expansionary, or alternatively a decrease in real wages and depreciation would be unambiguously contractionary. However, that under less restrictive circumstances, when an appreciation does have a negative impact on net exports and the y-dot line is positively sloped, it is still possible for wage-led growth. The only limit to a wage-led expansion, when the positive effects of an increase in the wage share on consumption trumps the negative effects on net exports, would be an external constraint, which precludes excessive expansion of output. ${ }^{23}$ Note that a situation in which the level of potential output and the real exchange rate that is compatible with a stable distributive situation imply a persistent external deficit cannot be sustainable for long periods, unless the country holds the international reserve currency.

\footnotetext{
${ }^{23}$ These are consistent with the balance-of-payments constraint analysis that emphasizes the external constraint as the 'binding constraint.' McCombie \& Thirlwall (1994).
} 
Otherwise a combination of real depreciation and lower normal output would be required to rebalance the external position. ${ }^{24}$

Finally, it is important to note that under certain circumstances the import coefficient might not be completely autonomous from the domestic distributive conflict. In other words, in an effort to maintain higher levels of unemployment, and to avoid strengthening the labor class, capitalists might promote a move of their plants to low income countries, or in the case of a developing country, to other developing countries with lower wages, in an explicit strategy of deindustrialization. The consequent increase in $m$ leads to a counter-clockwise rotation in the $y-$ dot curve. If lower real wages, and an increased import coefficient, are both pursued then the result might be a significant reduction of potential output and a depreciation of the currency in real terms.

This suggests that reducing wages to increase exports might be a self-defeating game as a strategy for economic growth, and neo-mercantilist policies of this type are doomed to failure. For a developed country, which even in the face of some deindustrialization is able to maintain an active industrial sector, with high levels of productivity growth and significant export dynamism, the danger comes from the negative effects that the lack of growth of demand would have on the reciprocal demand for its exports from trading partners. Think of the US and Germany as exemplar cases of this situation. For developing countries, the risk is directly related to the negative effects of deindustrialization on productivity growth, since it is wellknown that productivity in the industrial sector is the key to overall growth in efficiency.

\section{REAL WAGE, GDP AND DEBT-LED GROWTH: AN EMPIRICAL ANALYSIS}

If our scenario in the previous section is correct, then growth with lower or stagnating real wages could not be a very common phenomenon. The available empirical evidence for the period 1960-2012 for a group of 19 advanced economies shows that real wages declined over

\footnotetext{
${ }^{24}$ We could add an additional complication to the model. We could assume that foreign demand drives domestic exports, but these, in turn, depend on the level of domestic demand. In other words, foreign countries demand from the home economy, but this economy's domestic market is so dominant in world markets, that when its growth slows down it brings down global demand; this would be a hegemonic country. The idea would be that foreign countries could not import if the hegemonic country does not grow, and in this case a fall in the domestic real wages in the hegemonic country has an additional negative impact on its own exports, since it affects foreign demand. This suggests that export led growth is much less likely in a hegemonic country like the US.
} 
time especially since the 1980 s decade for all economies without exception. ${ }^{25}$ The average rate of growth of real wages which stood at 4.2\% and 3.5\% in the periods 1960-1970 and 19701980, decreased by more than 3 percentage points in the 1990s and especially in the 2000s decades, reaching $1.5 \%$ and $0.7 \%$, respectively.

The reduction in real wage growth was accompanied by a fall in the wage share for the majority of the economies considered in the sample. On average between 1960 and in 1980 wages represented roughly $63 \%$ of GDP. In 2012, the wage share shrank to $56 \%$.

This observed trend in real wages over time seems to be consistent with the overall growth conditions for most economies. On average, the group of economies here considered registered a rate of growth of GDP on 5.4\%, 3.9\% and 2.6\% for the periods 1960-1970, 19701980 and 2000-2012 respectively (Table 1).

In fact the consistency between the movement in wages and GDP is underscored by the fact that there is a positive and, for the most part, significant association between the rate of growth of real wages and that of $\mathrm{GDP}^{26}$. This is illustrated in table 1 which shows the static correlation coefficient for a group of 19 advanced economies between the rate of growth of real GDP and that of real wages for the period 1961-2012. The correlation coefficient is positive in $90 \%$ of the cases considered. It is both positive and statistically significant (at the $95 \%$ level of confidence) in $74 \%$ of the cases considered.

These time series results are corroborated by an analysis of higher frequency (quarterly) data for a subset of countries (United States, Frances, United Kingdom, Canada, Germany, Italy, Australia and Japan) using spectral analysis. Spectral analysis provides an analysis of data in the frequency domain and thus has the advantage that it permits the decomposition of comovement at different frequencies, that is, into those at short, medium and long-term frequencies. ${ }^{27}$ Table 2 shows two indicators of correlation in the frequency domain, the dynamic correlation coefficient and a coherency indicator.

\footnotetext{
${ }^{25}$ In all of the empirical analysis real wages are proxied by real wage compensation. Most of the econometric work was undertaken using Scilab 5.4.1. and Grocer. See, Dubois \& Michaux (2011).

${ }^{26}$ Similar results favorable to a wage-led interpretation of the data have been found by Stockhammer et al (2009) for European economies and by Lavoie \& Stockhammer (2012) for European countries plus Japan, and the United States. Onaran \& Galanis (2012) find wage-led result to be consistent with a broader sample of countries. Skott \& Zipperer (2012) suggest that similar results favor the Kaldorian view of the investment function.

${ }^{27}$ The frequency of a cycle $(\lambda)$ is related to the number of observation (p) by the following formula, $=\frac{2 \pi}{\lambda}$.
} 
The dynamic correlation coefficient $\left(\rho_{x y}(\lambda)\right)$ measures the extent to which the cyclical components of two series (in this case of the GDP series, say of country $i, j$ ) are in synchronicity at a given frequency. ${ }^{28}$ Coherence can be viewed as a partial $R^{2}$.

${ }^{28}$ Dynamic correlation applies to stationary series. Formally the dynamic correlation coefficient between two series (say, $\mathrm{x}$ and $\mathrm{y}$ ) is defined as,

(6) $\rho_{x y}(\lambda)=\frac{\operatorname{Real}\left(S_{x y}(\lambda)\right)}{\sqrt{S_{x}(\lambda) S_{y}(\lambda)}}$

Where, $S_{x y}(\lambda)$ is the cross-spectral density of $\mathrm{x}$ and $\mathrm{y}$ at the frequency $\lambda$ and $S_{x}(\lambda) S_{y}(\lambda)$ are the spectral density functions of $\mathrm{x}$ and $\mathrm{y}$. The spectral density function is defined as $S_{i}(\lambda)=\frac{1}{2 \pi} \sum_{h=-\infty}^{\infty} e^{-i h \lambda} \gamma_{i h}(h)$.

See, Martin \& Guarda (2011), Croux et al. (2003) and Iacobucci (2003). 
Table 1: Growth of real wages (real compensation per employee) and real GDP; correlation coefficient between the rate of growth of real wage (real compensation per employee) and GDP for selected advanced economies for 1961-2012 (Annual data).

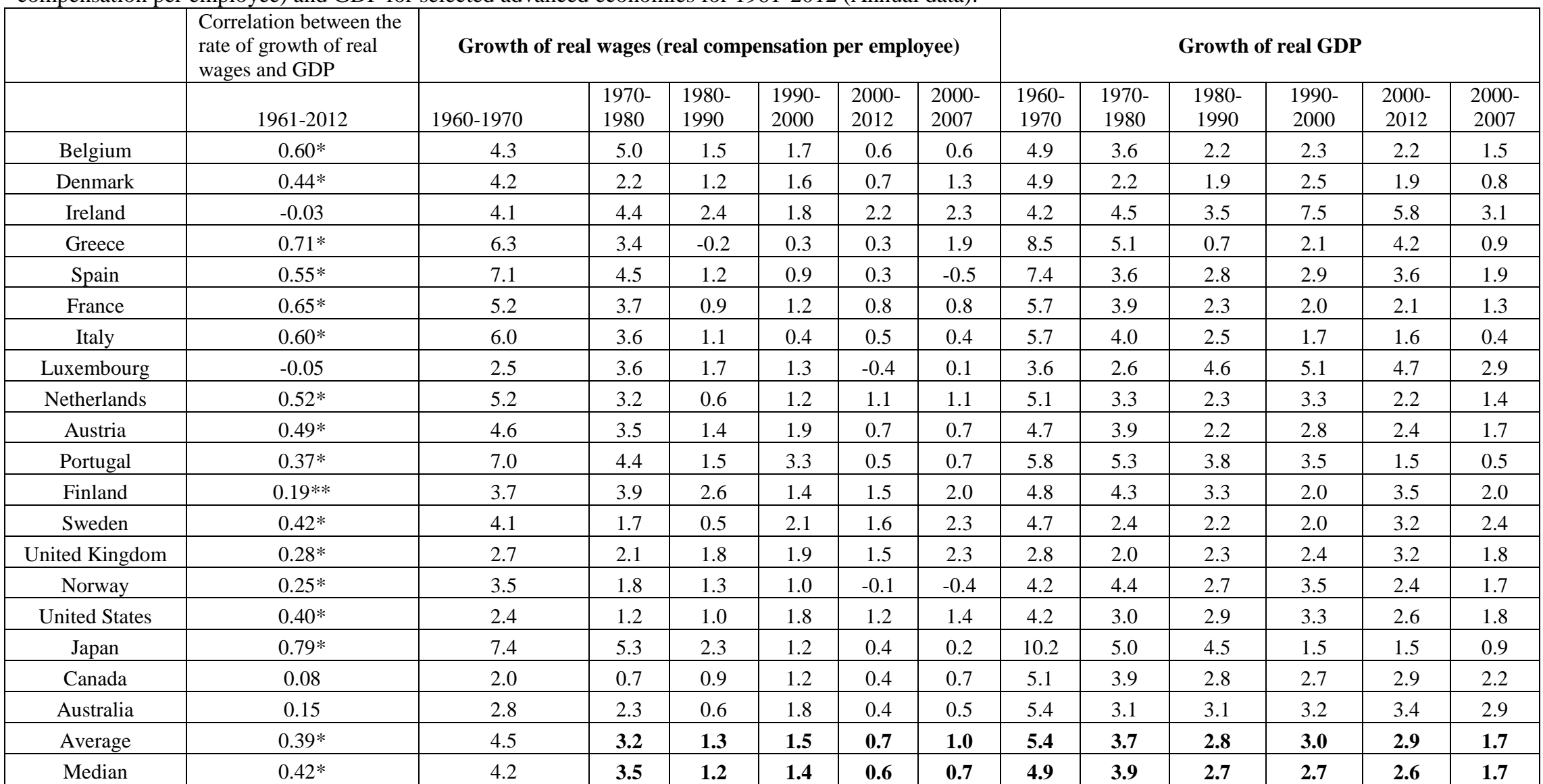

Note: Real wages are proxied by real wage compensation * denotes significant at the $95 \%$ and ** at the $90 \%$ level of confidence. The statistical significance of the correlation coefficient was determined on the basis of the formula: $\rho=\frac{r(\sqrt{n-2)}}{\sqrt{-r}}$ where $r$ is the simple correlation coefficient and $n$ the number of observations.

$\rho$ follows a student-t distribution.

Source: Authors' own computations on the basis of Ameco database (2013). 
Table 2: Dynamic correlation and coherence indicators for selected advanced economies in the low, medium and high frequency domain. 1960-2013. Quarterly data.

\begin{tabular}{|c|c|c|c|c|c|c|c|c|c|}
\hline Country & \multicolumn{3}{|c|}{ Real Wages and GDP } & \multicolumn{3}{|c|}{ Real Wages and Investment } & \multicolumn{3}{|c|}{ Real Wages and Exports } \\
\hline & $\begin{array}{c}\text { Low } \\
\text { Frequency }\end{array}$ & $\begin{array}{c}\text { Medium } \\
\text { Frequency }\end{array}$ & $\begin{array}{c}\text { High } \\
\text { Frequency }\end{array}$ & $\begin{array}{c}\text { Low } \\
\text { Frequency }\end{array}$ & $\begin{array}{l}\text { Medium } \\
\text { Frequency }\end{array}$ & $\begin{array}{c}\text { High } \\
\text { Frequency }\end{array}$ & $\begin{array}{c}\text { Low } \\
\text { Frequency }\end{array}$ & $\begin{array}{c}\text { Medium } \\
\text { Frequency }\end{array}$ & $\begin{array}{c}\text { High } \\
\text { Frequency }\end{array}$ \\
\hline & \multicolumn{9}{|c|}{ Coherence } \\
\hline \multicolumn{10}{|l|}{ United States } \\
\hline France & 0.5 & 0.2 & 0.0 & 0.4 & 0.0 & 0.0 & 0.1 & 0.4 & 0.0 \\
\hline United Kingdom & 0.7 & 0.5 & 0.5 & 0.5 & 0.0 & 0.0 & 0.1 & 0.0 & 0.1 \\
\hline Canada & 0.55 & 0.15 & 0.15 & 0.55 & 0.15 & 0.15 & 0.0 & 0.1 & 0.0 \\
\hline \multicolumn{10}{|l|}{ Germany } \\
\hline Italy & 0.25 & 0.10 & 0.0 & 0.4 & 0.0 & 0.0 & 0.0 & 0.0 & 0.2 \\
\hline Australia & 0.4 & 0.2 & 0.4 & 0.0 & 0.0 & 0.5 & 0.0 & 0.1 & 0.3 \\
\hline Japan & 0.45 & 0.0 & 0.2 & 0.7 & 0.0 & 0.2 & 0.2 & 0.0 & 0.0 \\
\hline & \multicolumn{9}{|c|}{ Dynamic Correlation } \\
\hline \multicolumn{10}{|l|}{ United States } \\
\hline France & 0.4 & 0.2 & 0.3 & 0.7 & 0.2 & 0.0 & 0.63 & 0.0 & 0.3 \\
\hline United Kingdom & 0.5 & 0.1 & 0.1 & 0.64 & 0.1 & 0.1 & 0.4 & -0.1 & 0.3 \\
\hline Canada & 0.75 & 0.2 & 0.3 & 0.75 & 0.2 & 0.3 & 0.2 & 0.2 & 0.0 \\
\hline \multicolumn{10}{|l|}{ Germany } \\
\hline Italy & 0.60 & 0.1 & 0.0 & 0.6 & 0.2 & 0.2 & 0.0 & 0.2 & 0.3 \\
\hline Australia & 0.65 & 0.4 & 0.55 & 0.2 & $-0,1$ & 0.2 & 0.0 & 0.1 & 0.1 \\
\hline Japan & 0.60 & 0.0 & -0.5 & 0.8 & -0.2 & 0.3 & 0.4 & 0.1 & 0.0 \\
\hline
\end{tabular}

Note: The period 1960 to 2013 refers to encompassing time domain. Data for that period was not available for all countries. See Annex for a detailed overview of the countries, variables and respective time periods. Real wages are proxied by real wage compensation Significant values for dynamic correlation and coherence are highlighted.

Source: Authors' own computations on the basis of the Federal Reserve Bank of St. Louis data (FRED). http://research.stlouisfed.org/fred2/ 
When, at a given frequency, the dynamic correlation coefficient $\left(\rho_{x y}(\lambda)\right)$ is equal to unity $(=1)$, the two series in question are perfectly synchronized at that given frequency. Or in other words, to use a time series expression, both series are 'cointegrated' at that frequency. Contrarily when the dynamic correlation coefficient $\left(\rho_{x y}(\lambda)\right)$ is equal to -1 , then the two series in question are 'de-synchronized' or to put it another way, one series (say, $\mathrm{x}$ ) has a peak when another series (say, y) exhibits a trough.

In line with the above results, the coherency and dynamic correlations between real wages and GDP are positive and strongest for both dynamic correlation and coherence at low frequencies (LF) which correspond to long-term (persistent) fluctuations and weakest for higher frequencies (HF) which correspond to short-term fluctuations.

As Table 2 shows, the dynamic correlation coefficient between real wages and GDP is significant for all the cases considered. In the case of the coherency indicators only one country (Italy) shows an indicator that is insignificant. In addition, the evidence also shows a positive and for the most part significant association between real wages and investment. Note however, that there is no dynamic association between real wages and exports in the long run indicating perhaps the fact that price effects are not the main determinant variable of export performance and giving credence to the Balance-ofPayments Constraint approach to growth.

In order to complete the analysis the relationship between real wages and growth was also examined from the perspective of cycle behavior using wages, GDP, consumption, investment, exports (all expressed in real terms) and capacity utilization. Cycle analysis characterizes fluctuations in terms of duration and intensity and concordance. ${ }^{29}$ The duration (D) of an expansion is defined as the ratio the total number of quarters of expansion to the total number of peaks in a series. That is,

\footnotetext{
${ }^{29}$ The Classical Cycle methodology was used. The Classical Methodology views the cycle as a set of turning points of a time series representing the level of aggregate economic activity without consideration to a trend (Harding and Pagan, $2001 \&$ 2002). The inflection points of the series are then used as a basis to analyze the cycle in terms of a series of indicators such as the duration, intensity of an expansion (troughto-peak) and a contraction (peak-to-trough) and the degree of coincidence between two given time series. Central to this approach is the identification of the turning points of a series. The turning points of a series are usually identified using the Bry-Boschan algorithm (1971) developed originally for monthly data and adapted to deal with quarterly observation by Harding and Pagan (2002). The algorithm consists in identifying local maxima and minima for a given series following a logarithmic transformation using
} 
(7) $D=\frac{\sum_{t=1}^{T} S_{t}}{\sum_{t=1}^{T-1}\left(1-S_{t+1}\right) S_{t}}$

Where, $\mathrm{S}$ is a binary variable, which takes a 1 during an expansion and 0 during a contraction. ${ }^{30}$ The numerator in (1) $\left(\sum_{t=1}^{T} S_{t}\right)$ denotes the total duration of expansions and the denominator $\left(\sum_{t=1}^{T-1}\left(1-S_{t+1}\right) S_{t}\right)$ measures the number of peaks in the series. For its part the intensity or amplitude (A) of the expansion is measured as the ratio of the total change in aggregate economic activity to the total number of peaks. That is:

(8) $A=\frac{\sum_{t=1}^{T} S_{t} \Delta Y_{t}}{\sum_{t=1}^{T-1}\left(1-S_{t+1}\right) S_{t}}$

Where, $\mathrm{Y}$ is a measure of economic activity (GDP in our cases) and the numerator in (4) $\left(\sum_{t=1}^{T} S_{t} \Delta Y_{t}\right)$ is the total change in economic activity. Finally the concordance (coincidence) indicator measures the proportion of time two series ( $\mathrm{x}$ and $\mathrm{y}$ ) are in the same phase of the cycle. The concordance (coincidence) index is defined as:

(9) $I=T^{-1}\left[\sum_{t=1}^{T} S_{x t} S_{y t}+\sum_{t=1}^{T}\left(1-S_{x t}\right)\left(1-S_{y t}\right]\right.$

specific censoring rules (Bry-Boschan, 1971; Male, 2009). These include the specification of two quarters for a minimum duration for a single phase, and a minimum duration of five quarters for a complete cycle (Harding and Pagan, 2002). The peak for a series $y_{t}$ is found when, $y_{t}$ is greater than $y_{t \mp k}$ for $k=1,2$. Similarly, the trough for a series $y_{t}$ is found when, $y_{t}$ is less than $y_{t \mp k}$ for $k=1,2$. The algorithm excludes the occurrence of two successive peaks or troughs.

${ }^{30}$ Similarly the duration and amplitude for contractions are computed using $c_{i, t}=1 i s_{i . t}$. 
Table 3: Cycle indicators for capacity utilization, investment, GDP, consumption, real wages and exports for selected advanced economies on the basis of quarterly data (1960-2013)

\begin{tabular}{|c|c|c|c|c|c|c|}
\hline & $\begin{array}{c}\text { Capacity } \\
\text { Utilization }\end{array}$ & Investment & GDP & Consumption & Real Wages & Exports \\
\hline \multicolumn{7}{|c|}{ Average duration from peak to peak } \\
\hline United States & 15.3 & 14.9 & 30.6 & 45.7 & 24.8 & 22.7 \\
\hline France & 13.9 & 21.7 & 37.5 & 24.7 & 34.0 & 16.9 \\
\hline United Kingdom & 17.7 & 13.3 & 31.7 & 22.1 & 20.3 & 19.9 \\
\hline Canada & $\ldots$ & 20.2 & 38.0 & 42.0 & 27.3 & 23.8 \\
\hline Germany & 15.3 & 23.6 & 17.1 & 22.3 & 21.7 & 15.4 \\
\hline Italy & 14.5 & 20.8 & 23.6 & 22.6 & 22.3 & 15.1 \\
\hline Australia & 14.0 & 18.5 & 20.4 & 47.5 & 25.4 & 15.1 \\
\hline Japan & $\ldots$ & 11.8 & 15.0 & 12.8 & 14.7 & 18.3 \\
\hline Average & 15.1 & 18.1 & 25.2 & 30.0 & 23.8 & 18.4 \\
\hline \multicolumn{7}{|c|}{ Average Amplitude from trough to peak } \\
\hline United States & 6 & 28 & 25 & 37 & 21 & 18 \\
\hline France & 4 & 12 & 15 & 10 & 7 & 13 \\
\hline United Kingdom & 6 & 9 & 13 & 9 & 9 & 13 \\
\hline Canada & & 13 & 20 & 23 & 14 & 16 \\
\hline Germany & 6 & 17 & 8 & 9 & 6 & 16 \\
\hline Italy & 5 & 11 & 9 & 9 & 7 & 16 \\
\hline Australia & $\ldots$ & 17 & 8 & 24 & 14 & 10 \\
\hline Japan & $\ldots$ & 5 & 7 & 5 & 5 & 36 \\
\hline Average & 5.4 & 14.0 & 13.1 & 15.8 & 10.4 & 17.3 \\
\hline
\end{tabular}

Note: The period 1960 to 2013 refers to encompassing time domain. Data for that period was not available for all countries. See Annex for a detailed overview of the countries, variables and respective time periods. Real wages are proxied by real wage compensation

Source: Authors' own computations on the basis of the Federal Reserve Bank of St. Louis data (FRED). http://research.stlouisfed.org/fred2/ 
Table 4: Concordance Indicator for selected pairs of variables and advanced economies. 1960-2013 (quarterly data)

\begin{tabular}{|c|c|c|c|c|c|c|c|c|}
\hline & $\begin{array}{l}\text { United } \\
\text { States }\end{array}$ & France & $\begin{array}{c}\text { United } \\
\text { Kingdom }\end{array}$ & Canada & Italy & Australia & Germany & Japan \\
\hline Real Wages and Capacity Utilization & 0.77 & 0.87 & 0.51 & $\ldots$ & 0.63 & 0.55 & 0.42 & $\ldots$ \\
\hline Real Wages and Investment & 0.78 & 0.73 & 0.68 & 0.80 & 0.70 & 0.75 & 0.25 & 0.63 \\
\hline Real Wages and GDP & 0.88 & 0.90 & 0.80 & 0.90 & 0.73 & 0.72 & 0.30 & 0.88 \\
\hline Real Wages and Consumption & 0.85 & 0.87 & 0.85 & 0.89 & 0.74 & 0.81 & 0.39 & 0.63 \\
\hline Real Wages and Exports & 0.90 & 0.81 & 0.65 & 0.76 & 0.79 & 0.26 & 0.46 & 0.73 \\
\hline Investment and capacity utilization & 0.85 & 0.74 & 0.66 & $\ldots$ & 0.73 & 0.38 & 0.59 & $\ldots$ \\
\hline Investment and GDP & 0.77 & 0.75 & 0.76 & 0.84 & 0.86 & 0.69 & 0.86 & 0.83 \\
\hline Investment and exports & 0.85 & 0,62 & 0.67 & 0.70 & 0.65 & 0.28 & 0.63 & 0.68 \\
\hline Capacity utilization and GDP & 0.72 & 0.65 & 0.52 & $\ldots$ & 0.76 & 0.50 & 0.61 & $\ldots$ \\
\hline Capacity Utilization and exports & 0.66 & 0.63 & 0.64 & $\ldots$ & 0.73 & 0.50 & 0.66 & $\ldots$ \\
\hline GDP and exports & 0.84 & 0.83 & 0.76 & 0.77 & 0.81 & 0.33 & 0.80 & 0.96 \\
\hline
\end{tabular}

Note: Following Harding and Pagan (2006), the statistical significance of the concordance indicators was computed from the regression $\frac{S_{y t}}{\hat{\sigma}_{s x} \hat{\sigma}_{s y}}=c+\rho_{s} \frac{S_{x t}}{\hat{\sigma}_{s x} \hat{\sigma}_{s y}}+u_{t}$

Where, $\hat{\sigma}_{s x}, \hat{\sigma}_{s y}$ are the estimated standard deviations of $S_{x}$ and $S_{y} ; \rho_{s}$ is a correlation coefficient and $u_{t}$ is a random error. The hypothesis of no concordance corresponds to a correlation coefficient of $\rho_{s}=0$ The t statistic of the correlation coefficient is obtained by using GMM estimations with HAC heteroscedastic and autocorrelation consistent standard errors. In this procedure Bartlett Kernel and West fixed bandwiths are selected. Harding and Pagan (2006), Male (2009).

The period 1960 to 2013 refers to encompassing time domain. Data for that period was not available for all countries. See Annex for a detailed overview of the countries, variables and respective time periods. Real wages are proxied by real wage compensation

Source: Authors' own computations on the basis of the Federal Reserve Bank of St. Louis data (FRED). http://research.stlouisfed.org/fred2/ 
Where, $\mathrm{T}$ is the number of observations. As in the case of the other cycle indicators if a series x (y) is in an expansion phase, then $S_{x t}=1\left(S_{y t}=1\right)$. Contrarily if a series x (y) is in a contraction phase, then $S_{x t}=0\left(S_{y t}=0\right)$. The concordance indicator (I) takes a value of 1 if the two series in question ( $\mathrm{x}$ and $\mathrm{y}$ ) are perfectly synchronized in terms of the duration of their expansion and contraction phases. When the series are perfectly unsynchronized the concordance index is equal to $0(I=0)$.

The evidence presented in Tables 3 and 4 on cycle behavior show that the real wage, consumption and GDP cycles exhibit the most similarity in terms of duration measured from peak-to-peak on a quarterly basis. On an average basis the real wage cycle lasts roughly as long as the GDP cycle (24-25 quarters). By contrast investment, capacity utilization and exports are the variables that exhibit the highest frequency cycles. The average duration of the cycle for investment and exports is 18 quarters and 15 quarters for capacity utilization.

Also, the real wage exhibits, in the majority of cases the highest degree of synchronicity with real GDP relative to any other variable under consideration. Both variables are in the same phase of the cycle between $80 \%$ and $90 \%$ of the time for the United States, France, the United Kingdom, Canada and Japan. In the cases of Italy and Australia they are in the same phase of cycle $73 \%$ and $72 \%$ of the time (Table 4 ).

Furthermore, the real wage cycle is also highly concordant, in the majority of the cases with other variables such as investment and exports. The cycle of the real wage is in the same phase of the cycle between $70 \%$ and $80 \%$ for the United States, France, Canada, Italy and Australia. In comparison to exports, both variables are in the same phase of the cycle, more than $70 \%$ of the time in the cases of Italy, Canada and Japan; and more than $80 \%$ of the time for the United States and France (Table 4).

These results underscore the fact that real wages move pro-cyclically with all of the variables considered including GDP, investment, capacity utilization and exports. In so far as, the real wage has any effect at all on these variables, as postulated by NeoKaleckian models, the effect is positive. In other words, over the cycle higher real wages imply higher growth of GDP, and greater investment and fuller capacity utilization. In this sense in so far as cycle fluctuations affect long-term growth the decline of growth in GDP over the period 1960-2012 (Table 1) can be partly attributed to wages. Wages are 
also pro-cyclical with exports, underlying the fact that higher wages by themselves do not necessarily harm the overall competitive potential of an economy.

A final result worth highlighting is that although real wages have a positive and pro-cyclical relationship with GDP over long periods of time and also over the cycle, their intensity (measured by the average amplitude) and especially cumulative effect is lower relative to the other variables included in the analysis that are considered as determinants of growth, and especially at the domestic level with respect to consumption. Real wages have an average amplitude from peak-to-trough is $10 \%$ for wages, while for consumption it is $16 \%$. At the country level the differences between consumption and real wages are highest for Canada (14\% and 23\%) and Australia (14\% and 24\%) and especially for the United States (21\% and 37\% respectively).

The fact that wages exhibit lower amplitude relative to GDP is consistent with the evidence presented in Table 1 regarding the decline in the wage share. The fact that consumption tends to display a higher amplitude and accumulated effect than real wages implies at the same time that another factor besides wages is sustaining consumption. That other factor is debt.

In the case of the United States and other countries increasing debt has allowed households to expand consumption, in spite of the reduced growth in real wages. In other words, debt has rendered consumption independent, to a certain extent and for a given period of time, of income. In so doing debt has given consumption the potential to act as an autonomous component of aggregate demand and thus to become a linchpin for economic growth. ${ }^{31}$ This stylized fact has been mistaken in the empirical literature as a profit-led boom. In fact, debt has become over time a crucial element in driving consumption and expansions.

To illustrate this point Figure 5 shows a 44 quarter rolling coincidence indicator between the GDP cycle and that of the liabilities of: (i) credit market instruments for financial businesses (corporations); (ii) consumer credit (HCL) and home mortgages (HM) for households and non-profit organizations as a percentage of GDP for the period 1969q3-2009q2 for the United States. The figure shows that the coincidence indicator increases for all the variables considered. That is these variables (credit market

\footnotetext{
${ }^{31}$ See, Barba and Pivetti (2009) and Onaran et al. (2011).
} 
instruments for financial businesses (corporations), consumer credit and mortgages) became more pro-cyclical over time. The largest increase in the coincidence index is registered by home mortgages, which rose from roughly 0.6 in the 1980 s to reach 0.9 by the beginning of the 2000s.

Figure 5: United States. Rolling coincidence (concordance) indicator between the GDP cycle and credit market instruments for financial businesses (corporations); consumer credit (HCL); and home mortgages for households and non-profit organizations. 1969q3-2009q2. Quarterly Data.

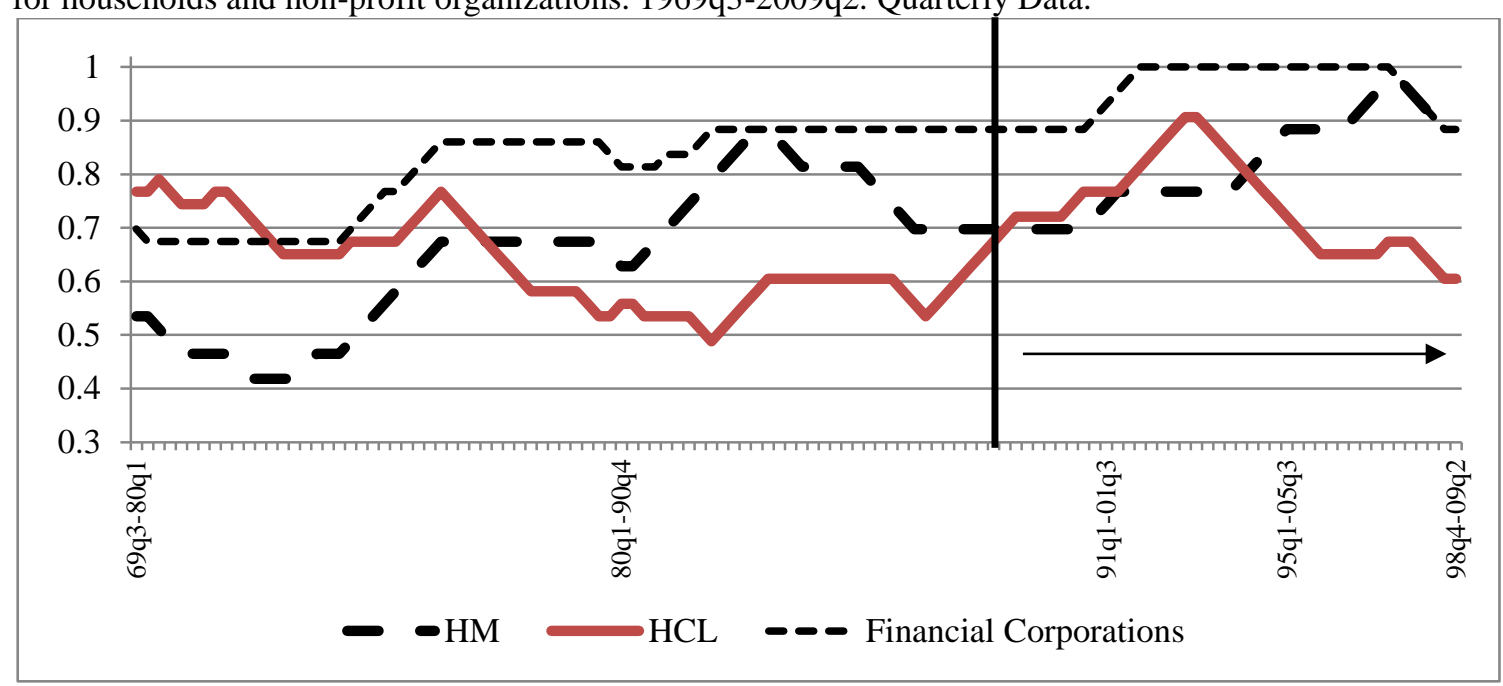

Note: All financial variables refer to liabilities (seasonally adjusted)

Source: Authors' own computations on the basis of the Federal Reserve Bank of St. Louis data (FRED). http://research.stlouisfed.org/fred2/

The fact that the highest index value is attained by financial business (corporations) whose liabilities display a one-to-one correspondence with the GDP cycle for most of the 1990s and 2000s, may reflect the fact that the benefits for capital have been financial and associated to higher interest rates. In this sense, the last three expansions have been more Wall Street debt-led, rather than profit-led investment. Wall Street, not Silicon Valley, defines the current American economy (even if the last is also important).

\section{CONCLUDING REMARKS}

Neo-Kaleckian models make the case for profit-led growth based on the predominance of profitability over the accelerator as a determinant of investment, or what 
amounts to the same thing, on the predominance of supply over demand side factors. The open economy analyses follow the same approach.

In this paper we try to recapture the importance of demand as determinant of short and long run growth. We place the focus of our analysis on the accelerator but argue at the same time that investment rather being autonomous or determined by profitability is in fact a derived demand.

Investment is determined by the adjustment of capacity to exogenous demand in order to reach the normal capacity utilization. The normal level of capacity utilization is determined in turn by the exogenous components of demand. Income distribution in Kaldorian models might have ambiguous effects on growth, but firms would not investment more if profits went up, if there is no increase in demand. In this sense, worsening income distribution might lead to higher growth if demand keeps going for some reason such as that an increase in private debt stimulates consumption.

The Kaldorian model developed in this paper is better equipped to deal with some of the issues relating income distribution to accumulation with effective demand in the long-run. In this sense it can reproduce Kaleckian results, in the sense that a lower wage share, or a higher profit share, are associated with higher levels of output growth. But rather than attribute these to the importance of supply side factors, traces the limits to a wage-led growth strategy to the balance-of-payments constraint.

The problems with the Neo-Kaleckian profit-led closure do not imply that income distribution has unambiguous effects on capital accumulation and growth. The nature of the effects of income distribution on growth is not, however, the one presumed, in general, in the Neo-Kaleckian models. External problems with wage-led growth in the periphery, and the possibility of debt-led growth in the center have made possible regimes that, while wage-led in nature, since higher wages shares associated to higher real wages would be essential for growth, behave like a profit-led one.

It is very likely given reasonable values of the parameters to obtain results that resemble the Neo-Kaleckian closure in a Kaldorian model. Higher wages and a more appreciated real exchange rate might lead to higher domestic demand, associated to the size of the supermultiplier, but the positive effect might be overweighed by the negative impact of both prices on external competitiveness. This suggests that globalization, the 
more open economic environment imposed by financial and trade liberalization over the last 30 years, and the stagnant real wages and reduced wage shares resulting from a weaker labor force would go hand in hand with higher rates of growth.

The empirical results seem to suggest that in the developed countries analyzed in this work the globalization cum profit-led expansion does not take place. In fact, the evidence suggests that real wages are positively correlated with GDP growth, and from a cyclical point view recoveries have been associated to higher real wages. Note that the cyclical aspect is part of the well-known stylized fact that real wages are pro-cyclical. Causality in this case runs most likely from the recovery of output and employment to real wages. The stronger bargaining position of workers in a boom explains why real wages tend to be higher in recoveries. However, the self-reinforcing effect of higher wages on the level of economic activity cannot be completely dismissed.

It is also important to note that in the case of developed countries, the effects of higher wages, and ceteris paribus, a more appreciated currency, might not be sufficient to create significant external constraints which would derail the process of economic expansion, as they would in a developing economy. In particular, developed countries are capable of financing external deficits with debt denominated in their own currency (i.e., do not suffer from the so-called 'original sin'). In this sense, the evidence suggests that wage-led is a viable strategy for the developed countries analyzed in our sample.

Finally, it is important to note that increasingly the expansions in the developed world have been associated not to higher wage shares, and higher supermultiplier values, as arguably was the case during the Golden Age of Capitalism, from the 1940s to the 1970s, but associated to greater degrees of private indebtedness. The downside of relying on debt-led growth is, of course, the greater risk of financial instability and the possibility of recurring crises. 


\section{REFERENCES}

Barba, A. \& Pivetti, M. 2009. "Rising Household Debt: Its Causes and Macroeconomic Implications: A Long-Period Analysis." Cambridge Journal of Economics, 33, pp. 113-137.

Bhaduri, A. 2008. "On the Dynamics of Profit-Led and Wage-Led Growth." Cambridge Journal of Economics, 32, pp. 147-160.

Bhaduri, A. \& Marglin, S. 1990. "Unemployment and the Real Wage: The Economic Basis for Contesting Political Ideologies." Cambridge Journal of Economics, 14, 375-393.

Blecker, R. 1989. "International Competition, Income Distribution and Economic Growth." Cambridge Journal of Economics, 13, 395-412.

- 1993. "Notes on the Cambridge Equation." Journal of Post Keynesian Economics. Vol. 16, No. 1. pp. 105-126.

- 1997. Institutions, Behaviour and Economic Theory - A Contribution to Classical-Keynesian Political Economy. Cambridge University Press, Cambridge.

Bry, G. \& Boschan, C. 1971. Cyclical Analysis of Time Series: Selected Procedures and Computer Programs. New York, National Bureau of Economic Research.

Cesaratto, S. 2013. "Neo-Kaleckian and Sraffian Controversies on Accumulation Theory." Quaderni del Dipartamento di Economia Politica e Statistica, Universita di Siena, No 650.

Croux, C. Forni, M. \& Reichlin, L. 2004. "A Measure of Co-movement for Economic Variables: Theory and Empirics." The Review of Economics and Statistics, May 2001, 83(2): 232-241.

Dubois, E. \& Michaux, E. 2011. Grocer. An Econometric Toolbox for Scilab. Last updated April 04, 2013 http://dubois.ensae.net/grocer.html.

Dutt, A. 1990. Growth, Distribution and Uneven Development. Cambridge: CUP.

- 2005. "Consumption, debt and growth.” In Setterfield M. (ed.): Interactions in Analytical Political Economy, M.E. Sharpe, Armonk, NY, pp. 155-78.

Dutt, A. \& Ros, J. 2009. "Long-run effects of aggregate demand fluctuations." Preliminary draft. Prepared for a Schwartz Center for Economic Policy Analysis conference on "The Long Term Impacts of Short Term Fluctuations: Theory, Evidence and Policy" at the Brookings Institution, November 5-6, 2009. 
Garegnani, P. \& Trezzini, A. 2005. "Cycles and Growth: A Source of Demand-Driven Endogenous Growth.” Review of Political Economy, 22(1), pp.119-125.

Godley, W. \& Cripps, F. 1983. Macroeconomics. Oxford, Oxford University Press.

Harding, D. \& Pagan, A. 2001. "Extracting, analysing and using cyclical information." Melbourne, Melbourne Institute of Applied Economics and Social Research.

— 2002. "Dissecting the cycle: a methodological investigation." Journal of Monetary Economics. 49: 365-381.

- 2005. "A Suggested Framework for Classifying the Modes of Cycle Research." Journal of Applied Econometrics. 20(2): 151-159.IMF (2009) World Economic Outlook. Washington D.C. : IMF.

Iacobucci, A. 2003 Spectral Analysis for Economic Time Series. Mimeo.

Kahn, R. 1959. "Exercises in the Analysis of Growth." Oxford Economic Papers, 11, pp. $143-156$.

Kaldor, N. 1951. "Mr. Hicks on the Trade Cycle.” Economic Journal, 61(244), pp. 832847.

—. 1957. "A Model of Economic Growth.” Economic Journal, 67(268), pp. 591624.

- 1960. Essays on Economic Stability and Growth. London, Duckworth.

- 1970. "The Case for Regional Policies.” Scottish Journal of Political Economy 17(3), pp. 337-348.

Krugman, P. \& Taylor, L. 1978. "Contractionary effects of devaluation.” Journal of International Economics, 8(3), pp. 445-456.

Lavoie, M. 1992. Foundations of Post Keynesian Economics. Aldershot, Edward Elgar.

—. 2006. "Do Heterodox Theories Have Anything in Common? A post-Keynesian Point of View." Intervention, 3(1), 87-112.

Lavoie, M. \& Stockhammer, E. 2012. "Wage-led Growth: Concepts, Theories and Policies." ILO Conditions of Work and Employment Series No. 41.

Lima G. \& Meirelles A. 2007. “A Macrodynamics of Debt Regimes, Financial Instability and Growth." Cambridge Journal of Economics, 31(4), pp. 563-580. 
Male, R. 2009. "Developing Country Business Cycles: Characterizing the Cycle and Investigating the Output Persistence Problem.” PhD Thesis. University of York. Department of Economics and Related Studies.

Marcuzzo, M. \& Rosselli, A. 2005. Economists in Cambridge: A Study through their Correspondence, 1907-1946. London, Routledge.

Marglin, S. \& Bhaduri, A. 1990. "Profit Squeeze and Keynesian Theory," in S. Marglin and J. Schor (eds.), The Golden Age of Capitalism: Reinterpreting the Postwar Experience. Oxford: Oxford University Press.

Martin D. \& Guarda, P. 2011. "Long-and Short-run Fluctuations: Measuring Cohesion in the Frequency Domain." Mimeo.

McCombie, J. \& Thirlwall, A. 1994. Economic Growth and the Balance of Payments Constraint. London, Macmillan.

Onaran, O., Stockhammer E., \& Grafl L. 2011. "Financialisation, Income Distribution and Aggregate Demand in the USA." Cambridge Journal of Economics. 35(4), pp. 637-661.

Onaran, O. \& Galanis G. 2012. "Wage-led and Profit-led Demand: A Global Mapping." Paper written for the project "New Perspectives on Wages and Economic Growth: the Potentials of Wage-led Growth."

Palley, T. 1994. "Debt, Aggregate Demand, and the Business Cycle: A Model in the Spirit of Kaldor and Minsky." Journal of Post Keynesian Economics. 16(3), pp. 371-390.

- 2010. "The Relative Permanent Income Theory of Consumption: A Synthetic Keynes-Duesenberry-Friedman Model." Review of Political Economy. 22(1), pp. 41-56.

Palumbo, A. 2003. Supply and Demand in Kaldor's Models of Economic Growth. Roma: Aracne.

Robinson, J. 1956. The Accumulation of Capital. London, Macmillan.

-1962. Essays in the Theory of Economic Growth. London, Macmillan.

Rowthorn, R. 1981. "Demand, Real Wages and Economic Growth." Thames Papers in Political Economy, Autumn: 1-39.

Skott, P. \& Zipperer, B. 2012 “An Empirical Evaluation of Three Post-Keynesian Models.” Intervention. 9(2), pp. 277-307. 
Serrano, F. 1995 "Long Period Effective Demand and the Supermultiplier." Contributions to Political Economy. 14, pp. 67-90.

Stockhammer, E. 1999. "Robinsonian and Kaleckian Growth: An Update on PostKeynesian Growth Theories." Vienna University of Economics Working Paper No. 67.

Stockhammer, E., Onaran, O., \& Ederer, S. 2009. "Functional Income Distribution and Aggregate Demand in the Euro Area." Cambridge Journal of Economics, 33(1): pp. 139-159.

Taylor, L. 1985. “A Stagnationist Model of Economic Growth.” Cambridge Journal of Economics. 9(4), pp. 383-403. 
ANNEX:

\begin{tabular}{|c|c|c|c|c|c|c|}
\hline \multirow[t]{2}{*}{ Country } & \multicolumn{6}{|c|}{ Variables (Description and time domain) } \\
\hline & GDP & $\begin{array}{l}\text { Gross formation of } \\
\text { fixed capital }\end{array}$ & Private Consumption & $\begin{array}{l}\text { Exports of goods and } \\
\text { services }\end{array}$ & $\begin{array}{l}\text { Rate of } \\
\text { Capacity Utilization }\end{array}$ & Wage Compensation \\
\hline United States & $\begin{array}{l}\text { Billions of Chained } \\
2005 \text { dollars } \\
\text { 1967-01-01 to 2013- } \\
01-01\end{array}$ & $\begin{array}{l}\text { Billions of Chained } \\
2005 \text { dollars } \\
\text { 1967-01-01 to 2013- } \\
01-01\end{array}$ & $\begin{array}{l}\text { Billions of Chained } \\
2005 \text { dollars } \\
\text { 1967-01-01 to 2013- } \\
01-01\end{array}$ & $\begin{array}{l}\text { Billions of Chained } \\
2005 \text { dollars } \\
\text { 1967-01-01 to 2013- } \\
01-01\end{array}$ & $\begin{array}{l}\text { Quarterly. Seasonally } \\
\text { Adjusted. Percent of } \\
\text { capacity } \\
\text { 1967-01-01 to 2013- } \\
01-01\end{array}$ & $\begin{array}{l}\text { Obtained by deflating } \\
\text { compensation of } \\
\text { employees (quarterly; } \\
\text { seasonally adjusted) } \\
\text { available from } \\
\text { 1967-01-01 to 2013- } \\
\text { 10-01 by GDP } \\
\text { implicit price deflator } \\
\text { (quarterly; seasonally } \\
\text { adjusted) available } \\
\text { from 1967-01-01 to } \\
\text { 2013-01-01 }\end{array}$ \\
\hline France & $\begin{array}{l}\text { Millions of chained } \\
\text { 2005 Euros } \\
\text { Quarterly. Seasonally } \\
\text { Adjusted } \\
\text { 1949-01-01 to 2013- } \\
01-01\end{array}$ & $\begin{array}{l}\text { Millions of chained } \\
\text { 2005 Euros } \\
\text { Quarterly. Seasonally } \\
\text { Adjusted } \\
\text { 1949-01-01 to 2013- } \\
01-01\end{array}$ & $\begin{array}{l}\text { Billions of chained } \\
2005 \text { dollars } \\
\text { Quarterly. Seasonally } \\
\text { Adjusted } \\
\text { 1947-01-01 to 2013- } \\
01-01\end{array}$ & $\begin{array}{l}\text { Millions of chained } \\
2005 \text { Euros } \\
\text { Quarterly. Seasonally } \\
\text { Adjusted } \\
\text { 1949-01-01 to 2013- } \\
01-01\end{array}$ & $\begin{array}{l}\text { Quarterly. Seasonally } \\
\text { Adjusted. Percent of } \\
\text { capacity } \\
\text { 1976-01-01 to 2013- } \\
04-01\end{array}$ & $\begin{array}{l}\text { Obtained by deflating } \\
\text { compensation of } \\
\text { employees (quarterly; } \\
\text { seasonally adjusted) } \\
\text { available from } \\
\text { 1981-01-01 to 2012- } \\
\text { 10-01 by GDP } \\
\text { implicit price deflator } \\
\text { (quarterly; seasonally } \\
\text { adjusted) available } \\
\text { from 1961-01-01 to } \\
\text { 2013-01-01 }\end{array}$ \\
\hline
\end{tabular}




\begin{tabular}{|c|c|c|c|c|c|c|}
\hline \multirow[t]{2}{*}{ Country } & \multicolumn{6}{|c|}{ Variables (Description and time domain) CONTINUATION } \\
\hline & GDP & $\begin{array}{l}\text { Gross formation of } \\
\text { fixed capital }\end{array}$ & Private Consumption & $\begin{array}{l}\text { Exports of goods and } \\
\text { services }\end{array}$ & $\begin{array}{l}\text { Rate of } \\
\text { Capacity Utilization }\end{array}$ & Wage Compensation \\
\hline United Kingdom & $\begin{array}{l}\text { Index } 2005=1.00 \\
\text { Quarterly. Seasonally } \\
\text { Adjusted } \\
1955-01-01 \text { to } 2013- \\
01-01\end{array}$ & $\begin{array}{l}\text { Index } 2005=1.00 \\
\text { Quarterly. Seasonally } \\
\text { Adjusted } \\
1955-01-01 \text { to } 2013- \\
01-01\end{array}$ & $\begin{array}{l}\text { Index } 2005=1.00 \\
\text { Quarterly. Seasonally } \\
\text { Adjusted } \\
\text { 1955-01-01 to 2013- } \\
01-01\end{array}$ & $\begin{array}{l}\text { Index } 2005=1.00 \\
\text { Quarterly. Seasonally } \\
\text { Adjusted } \\
1955-01-01 \text { to } 2013- \\
01-01\end{array}$ & $\begin{array}{l}\text { Quarterly. Seasonally } \\
\text { Adjusted. Percent of } \\
\text { capacity } \\
\text { 1985-01-01 to 2013- } \\
04-01\end{array}$ & $\begin{array}{l}\text { Obtained by deflating } \\
\text { compensation of } \\
\text { employees (quarterly; } \\
\text { seasonally adjusted) } \\
\text { available from } \\
\text { 1955-01-01 to 2012- } \\
\text { 10-01 by GDP } \\
\text { implicit price deflator } \\
\text { (quarterly; seasonally } \\
\text { adjusted) available } \\
\text { from 1955-01-01 to } \\
\text { 2013-01-01 }\end{array}$ \\
\hline Canada & $\begin{array}{l}\text { Index } 2005=1.00 \\
\text { Quarterly. Seasonally } \\
\text { Adjusted } \\
1961-01-01 \text { to } 2013- \\
01-01\end{array}$ & $\begin{array}{l}\text { Index } 2005=1.00 \\
\text { Quarterly. Seasonally } \\
\text { Adjusted } \\
1961-01-01 \text { to } 2013- \\
01-01\end{array}$ & $\begin{array}{l}\text { Index } 2005=1.00 \\
\text { Quarterly. Seasonally } \\
\text { Adjusted } \\
\text { 1961-01-01 to 2013- } \\
01-01\end{array}$ & $\begin{array}{l}\text { Index } 2005=1.00 \\
\text { Quarterly. Seasonally } \\
\text { Adjusted } \\
1961-01-01 \text { to } 2013- \\
01-01\end{array}$ & $\ldots$ & $\begin{array}{l}\text { Obtained by deflating } \\
\text { compensation of } \\
\text { employees (quarterly; } \\
\text { seasonally adjusted) } \\
\text { available from } \\
\text { 1981-01-01 to 2012- } \\
\text { 10-01 by GDP } \\
\text { implicit price deflator } \\
\text { (quarterly; seasonally } \\
\text { adjusted) available } \\
\text { from 1961-01-01 to } \\
\text { 2013-01-01 }\end{array}$ \\
\hline Germany & $\begin{array}{l}\text { Index } 2005=1.00 \\
\text { Quarterly. Seasonally } \\
\text { Adjusted } \\
1970-01-01 \text { to } 2013- \\
01-01\end{array}$ & $\begin{array}{l}\text { Index } 2005=1.00 \\
\text { Quarterly. Seasonally } \\
\text { Adjusted } \\
1970-01-01 \text { to } 2013- \\
01-01\end{array}$ & $\begin{array}{l}\text { Index } 2005=1.00 \\
\text { Quarterly. Seasonally } \\
\text { Adjusted } \\
\text { 1970-01-01 to 2013- } \\
01-01\end{array}$ & $\begin{array}{l}\text { Index } 2005=1.00 \\
\text { Quarterly. Seasonally } \\
\text { Adjusted } \\
1970-01-01 \text { to } 2013- \\
01-01\end{array}$ & $\begin{array}{l}\text { Quarterly. Seasonally } \\
\text { Adjusted. Percent of } \\
\text { capacity } \\
\text { 1960-01-01 to 2013- } \\
04-01\end{array}$ & $\begin{array}{l}\text { Obtained by deflating } \\
\text { compensation of } \\
\text { employees (quarterly; } \\
\text { seasonally adjusted) } \\
\text { available from } \\
\text { 1991-01-01 to 2012- } \\
\text { 10-10 by GDP } \\
\text { implicit price deflator } \\
\text { (quarterly; seasonally } \\
\text { adjusted) available } \\
\text { from 1970-01-01 to } \\
2013-01-01\end{array}$ \\
\hline
\end{tabular}




\begin{tabular}{|c|c|c|c|c|c|c|}
\hline \multirow[t]{2}{*}{ Country } & \multicolumn{6}{|c|}{ Variables (Description and time domain) CONTINUATION } \\
\hline & GDP & $\begin{array}{l}\text { Gross formation of } \\
\text { fixed capital }\end{array}$ & Private Consumption & $\begin{array}{l}\text { Exports of goods and } \\
\text { services }\end{array}$ & $\begin{array}{l}\text { Rate of } \\
\text { Capacity Utilization }\end{array}$ & Wage Compensation \\
\hline Italy & $\begin{array}{l}\text { Index } 2005=1.00 \\
\text { Quarterly. Seasonally } \\
\text { Adjusted } \\
\text { 1981-01-01 to 2013- } \\
01-01\end{array}$ & $\begin{array}{l}\text { Index } 2005=1.00 \\
\text { Quarterly. Seasonally } \\
\text { Adjusted } \\
\text { 1981-01-01 to 2013- } \\
01-01\end{array}$ & $\begin{array}{l}\text { Index } 2005=1.00 \\
\text { Quarterly. Seasonally } \\
\text { Adjusted } \\
\text { 1981-01-01 to 2013- } \\
01-01\end{array}$ & $\begin{array}{l}\text { Index } 2005=1.00 \\
\text { Quarterly. Seasonally } \\
\text { Adjusted } \\
\text { 1981-01-01 to 2013- } \\
01-01\end{array}$ & $\begin{array}{l}\text { Quarterly. Seasonally } \\
\text { Adjusted. Percent of } \\
\text { capacity } \\
\text { 1968-10-01 to 2013- } \\
04-01\end{array}$ & $\begin{array}{l}\text { Obtained by deflating } \\
\text { compensation of } \\
\text { employees (quarterly; } \\
\text { seasonally adjusted) } \\
\text { available from } \\
\text { 1992-01-01 to 2012- } \\
\text { 10-01 by GDP } \\
\text { implicit price deflator } \\
\text { (quarterly; seasonally } \\
\text { adjusted) available } \\
\text { from 1991-01-01 to } \\
\text { 2013-01-01 }\end{array}$ \\
\hline Australia & $\begin{array}{l}\text { Billions of Chained } \\
\text { 2007-2008 Australian } \\
\text { Dollars. Quarterly. } \\
\text { Seasonally Adjusted } \\
\text { 1959-07-01 to 2013- } \\
\text { 01-01 }\end{array}$ & $\begin{array}{l}\text { Index } 2005=1.00 \\
\text { Quarterly. Seasonally } \\
\text { Adjusted } \\
1960-01-01 \text { to } 2013- \\
01-01\end{array}$ & $\begin{array}{l}\text { Index } 2005=1.00 \\
\text { Quarterly. Seasonally } \\
\text { Adjusted } \\
1960-01-01 \text { to } 2013- \\
01-01\end{array}$ & $\begin{array}{l}\text { Index } 2005=1.00 \\
\text { Quarterly. Seasonally } \\
\text { Adjusted } \\
1960-01-01 \text { to } 2013- \\
01-01\end{array}$ & $\ldots$ & $\begin{array}{l}\text { Obtained by deflating } \\
\text { compensation of } \\
\text { employees (quarterly; } \\
\text { seasonally adjusted) } \\
\text { available from } \\
\text { 1959-07-01 to 2012- } \\
\text { 10-01 by GDP } \\
\text { implicit price deflator } \\
\text { (quarterly; seasonally } \\
\text { adjusted) available } \\
\text { from 1960-01-01 to } \\
\text { 2013-01-01 }\end{array}$ \\
\hline Japan & $\begin{array}{l}\text { Index } 2005=1.00 \\
\text { Quarterly. Seasonally } \\
\text { Adjusted } \\
\text { 1994-01-01 to 2013- } \\
01-01\end{array}$ & $\begin{array}{l}\text { Index } 2005=1.00 \\
\text { Quarterly. Seasonally } \\
\text { Adjusted } \\
1994-01-01 \text { to } 2013- \\
01-01\end{array}$ & $\begin{array}{l}\text { Index } 2005=1.00 \\
\text { Quarterly. Seasonally } \\
\text { Adjusted } \\
\text { 1994-01-01 to 2013- } \\
01-01\end{array}$ & $\begin{array}{l}\text { Index } 2005=1.00 \\
\text { Quarterly. Seasonally } \\
\text { Adjusted } \\
\text { 1994-01-01 to 2013- } \\
01-01\end{array}$ & $\ldots$ & $\begin{array}{l}\text { Obtained by deflating } \\
\text { compensation of } \\
\text { employees (quarterly; } \\
\text { seasonally adjusted) } \\
\text { available from } \\
\text { 1980-01-01 to 2013- } \\
\text { 10-01 by GDP } \\
\text { implicit price deflator } \\
\text { (quarterly; seasonally } \\
\text { adjusted) available } \\
\text { from 1994-01-01 to } \\
\text { 2013-01-01 }\end{array}$ \\
\hline
\end{tabular}

